\title{
Oligocene bivalve faunas from the Silesian Nappe, Polish Outer Carpathians: evidence of the early history of the Paratethys
}

\author{
Barbara STUDENCKA ${ }^{1, *}$, Sergey V. POPOV², Małgorzata BIEŃKOWSKA-WASILUK ${ }^{3}$ \\ and Radosław WASILUK ${ }^{4}$ \\ 1 Polish Academy of Sciences Museum of the Earth in Warsaw, Al. Na Skarpie 20/26, 00-488 Warszawa, Poland \\ 2 Russian Academy of Sciences, Borissiak Paleontological Institute, Profsoyuznaya 123, 117997 Moscow, Russia \\ 3 University of Warsaw, Faculty of Geology, wirki i Wigury 93, 02-089 Warszawa, Poland \\ 4 Polish Geological Institute - National Research Institute, Rakowiecka 4, 00-975 Warszawa, Poland
}

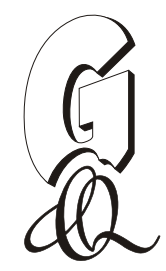

\begin{abstract}
Studencka, B., Popov, S.V., Bieńkowska-Wasiluk, M., Wasiluk, R., 2016. Oligocene bivalve faunas from the Silesian Nappe, Polish Outer Carpathians: evidence for the early history of the Paratethys. Geological Quarterly, 60 (2): 317-340, doi: 10.7306/gq.1296

The study is focused on the taxonomic inventory of an intriguing bivalve fauna from the Lower Oligocene Menilite Beds (Dynów Marls) within the Silesian Nappe, Polish Outer Carpathians. Sixteen bivalve species have been identified within the material collected in two small quarries in Jabłonica Polska near Krosno. Stratigraphic and geographic distributions of all recognized species are considered. This assemblage, the first of this kind in Poland and one of three recognized in the Outer Carpathians, shows clear affinities to coeval typical Solenovian faunas from Ukraine to Kazakhstan, with particular comparison made to bivalve faunas from the Menilite Formation (Subchert Member) within the Boryslav-Pokuttya Nappe, Ukrainian Outer Carpathians. Moreover, this study presents an overview of the main aspects and definitions of the date of the Paratethys origin. The main criterion used to define the time of the Paratethys birth is the distinct faunal turnover from the moderately diverse boreal or Tethyan bivalve faunas populating particular basins of the Northern Peri-Tethys in the earliest Oligocene to the uniform, highly endemic fauna inhabiting the newly formed semi-closed basin. This vast inland sea, named Paratethys, was populated by representatives of eight euryhaline bivalve families. They are characterized by extinct Paratethyan genera, such as Bessia Kojumdgieva et Sapungieva, Merklinicardium Popov, Korobkoviella Merklin, Urbnisia Goncharova, Ergenica G. Popov and Janschinella Merklin.
\end{abstract}

Key words: Bivalvia, Menilite Beds, Carpathian, Rupelian, Solenovian, Paratethys.

\section{INTRODUCTION}

Occurrences of the Paleogene molluscan faunas in the Polish Outer Carpathians are rare and limited to the deposits which originated through submarine debris flows. Thus far, findings of shallow-water molluscan faunas are noted only from olistostrome and olistolith bodies within the Silesian and Skole nappes (Fig. 1).

The oldest assemblage, showing also the greatest diversity, was discovered at Babica near Rzeszów (Paleocene Babica Clays; Skole Nappe) by Kropaczek (1910) who recognized 150 gastropod species. Unfortunately, his unpublished Ph.D thesis (Kropaczek, 1910) documenting 80 species was lost (see Studencka, 1986) and only a list of these gastropods is available (Kropaczek, 1917). Important palaeontological publications dealing with the molluscan fauna from the Paleocene

\footnotetext{
* Corresponding author, e-mail: bstudencka@go2.pl
}

Received: January 20, 2016; accepted: May 13, 2016; first published online: May 20, 2016
Babica Clays within both the Silesian and Skole nappes are those by Krach $(1963,1969)$. Within the fragmentary Kropaczek collection (housed in the Geological Museum of the Institute of Geological Sciences, PAS in Kraków) as well as in the material collected by Fleszar (1912) at Płosina, Rogala $(1919,1926)$ at Blizne, and in the material gathered by himself at Brzozów, Krach $(1963,1969)$ documented 251 gastropod species and 84 bivalve species.

The Eocene molluscan fauna is less diverse but - as in the Paleocene assemblages - is dominated both numerically and taxonomically by gastropods. The molluscan content of the upper Eocene of both the Silesian and Skole nappes is known through the work of Friedberg (1903), Wójcik (1903), Wiśniowski (1908), Kropaczek (1919), Rogala (1925), Jucha and Krach (1962) and Krach (1985). These reports show that the molluscan fauna appears in three areas - NE of Krosno (the Kobyle I and Kobyle II sites), SW of Rzeszów (Siedliska and Poręby) and close to Przemyśl (Koniusza and Kruhel Mały). This latter was documented by Wójcik (1903) who collected almost 150 molluscan specimens here. They include 45 gastropod species, seven bivalve species, six scaphopod species and one cephalopod, named by Wójcik as Spirulirostra szajnochae (1903: 544-545, pl. 6, fig. 32). Among the Upper Eocene 


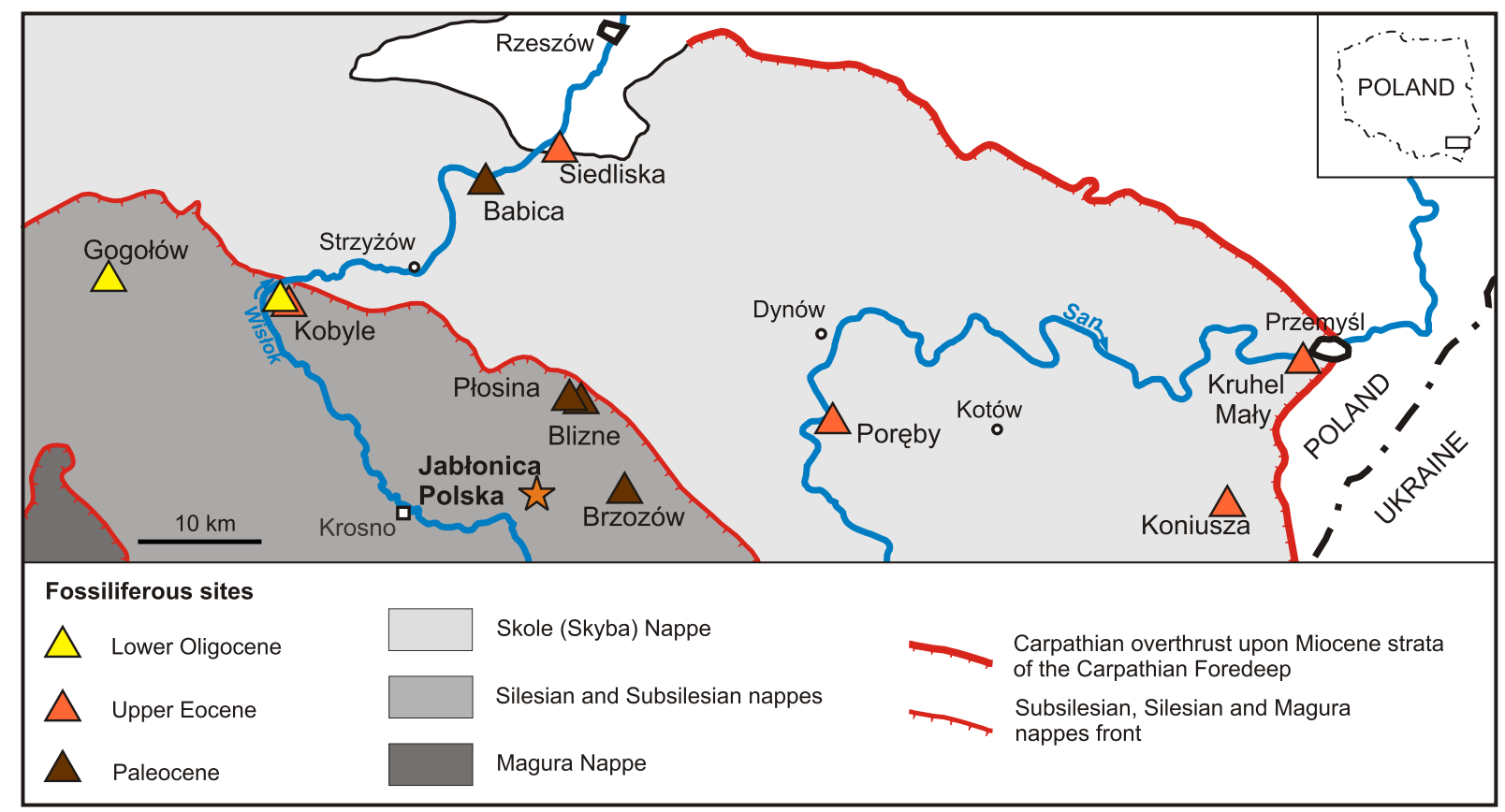

Fig. 1. Schematic map of the eastern part of the Polish Outer Carpathians (after Kotlarczyk and Leśniak, 1990, modified) showing locations of the Paleogene fossiliferous sites yielding molluscan material discussed in this paper

The new find of bivalves at Jabłonica Polska is marked by an asterisk; a more detailed map of the Jabłonica Polska area showing the location of the Menilite Beds sections yielding bivalves is shown in Figure 2

fossiliferous-bearing sites, the highest number of molluscan species was recorded in the Popiele Beds (Skole Nappe) in Koniusza near Przemyśl. Information on the molluscan fauna from the Popiele Beds was provided by Wiśniowski (1908), Rogala (1925), Krajewski and Urbaniak (1964), and Krach (1985). Within the fragmentary Wiśniowski and Rogala collections (stored in the Geological Museum of the Institute of Geological Sciences, PAS in Kraków) and in the material he himself collected, Krach (1985) recognized 84 gastropod species, 47 bivalve species and three scaphopod species.

Molluscs are very rare in the Lower Oligocene deposits of the Polish Outer Carpathians. Until now only twelve bivalve species, two gastropod species and one scaphopod species have been reported from the lowest coarse-grained unit (Siedliska Conglomerate or Siedliska Member) of the Menilite Beds (Menilite Formation of Kotlarczyk and Leśniak, 1990) at two sites: Gogołów and Kobyle III near Krosno (Jucha and Krach, 1962). The most important observation is that all these Carpathian molluscan faunas ranging from the Paleocene until the earliest Oligocene represent a typical normal marine biota. Despite these studies, however, knowledge of Paleogene Carpathian molluscan fauna is far from complete and is in need of comprehensive modern systematic revision.

The most recent fieldwork undertaken by the present authors in the vicinity of Krosno, Silesian Nappe, has yielded unique molluscan material, represented only by bivalves, mainly by cardiids and corbulids. It was obtained from the Dynów Marls (cropping out directly above the Kotów Chert) of the Menilite Beds, the origin of which is connected with submarine debris flows as it is the case with all other molluscan findings hereabouts. The major aim of our study focuses on the specific attribution of these Oligocene bivalves found in two exposures near the village of Jabłonica Polska and an indication of the stratigraphic and geographic distributions of these bi- valves. Another aim is a comparison of the taxonomic content of the two assemblages with other Early Oligocene faunas which inhabited the Carpathian Flysch basins. Special emphasis is placed on a bivalve fauna obtained from the basal part of the Menilite Formation (cropping out directly below the Chert Member) in the Boryslav-Pokuttya Nappe, Ukrainian Outer Carpathians. Detailed study at the species level (being extremely time-consuming because of poor state of preservation of the fossils) carried out on the bivalve shells from the newly explored exposures and those from the Boryslav-Pokuttya Nappe allows placing the Carpathian faunas in a wider palaeobiogeographic setting and is critical to tracing the Paratethys boundaries both in time and space. Accurate biostratigraphic dating of the bivalve fossils is essential to understand better the environmental changes within the Northern Peri-Tethys during the Early Oligocene, associated with the formation of the Paratethys.

\section{GEOLOGICAL SETTING}

The fieldwork undertaken by the junior authors (MB-W and RW) in 2007 in the northern, marginal part of the Silesian Nappe of the Polish Outer Carpathians resulted in discovery of two bivalve fossiliferous sites within the Oligocene Menilite Beds cropping out near Jabłonica Polska, $50 \mathrm{~km}$ south of Rzeszów, 10 km east of Krosno (Fig. 2). In this area the Menilite Beds are tripartite: the Kotów Cherts, at the base, are overlain by the Dynów Marls which pass upwards to the Rudawka Tractionites with the Tylawa Limestones intercalations (Fig. 3). The contact between the Upper Eocene Hieroglyphic Beds and Oligocene Menilite Beds in the area studied is of tectonic character. Local overthrusting of the Kotów Cherts on overturned Hieroglyphic Beds is observed (Wasiluk, 2015b). On the other 


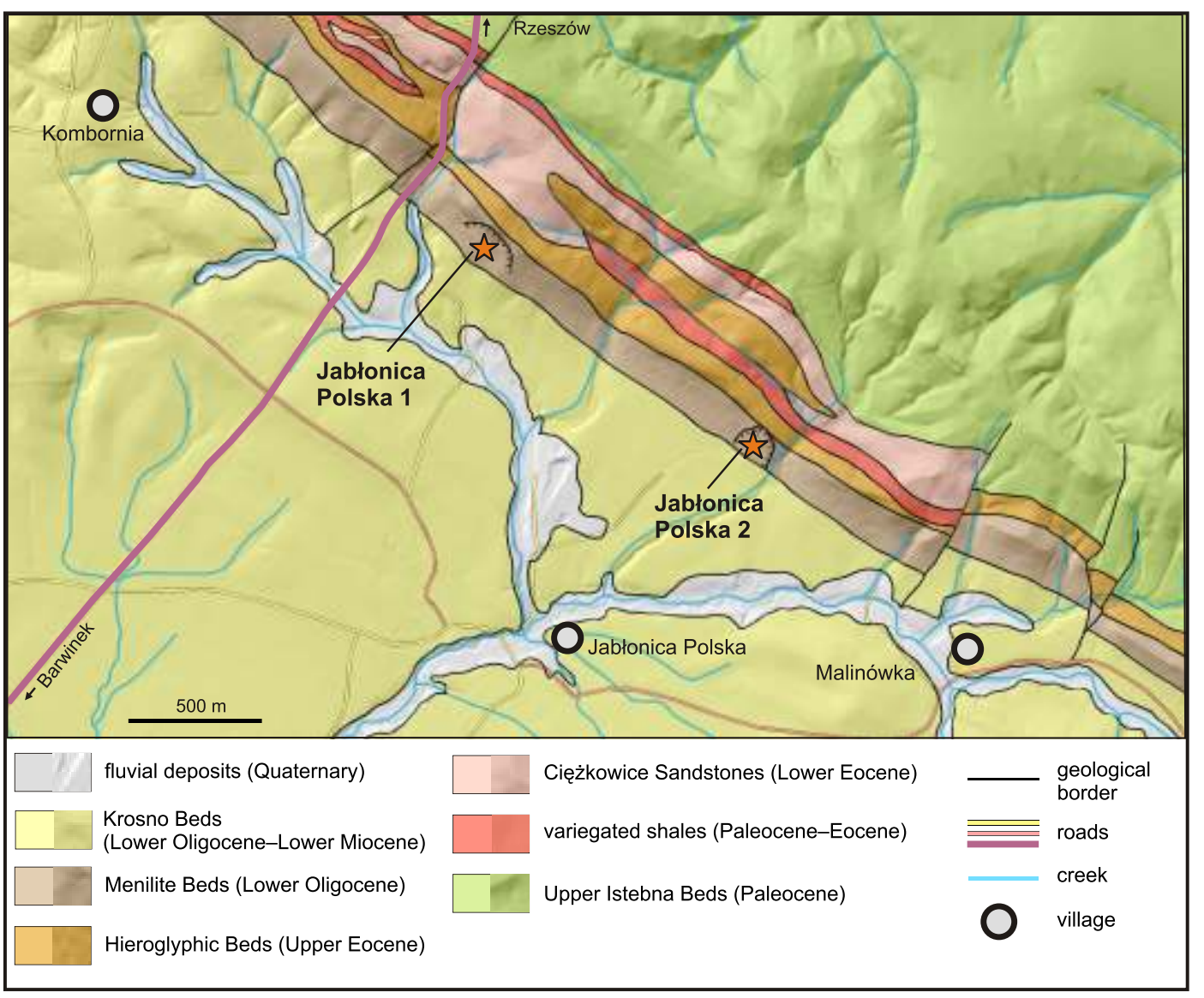

Fig. 2. Geological map of the Jabłonica Polska area adopted from Wasiluk (2015a, b)

Bivalve fauna sites at Jabłonica Polska are shown by asterisks

hand, in complete Lower Oligocene sections in the Silesian Nappe the Siedliska Conglomerate (Siedliska Member) or Subchert Beds constitute the lowest unit of the Menilite Beds, and it is overlain by the Kotów Cherts (Kotlarczyk et al., 2006). The latter (known also as the Chert Member of the Menilite Formation) forms an important correlation horizon within the Outer Carpathians (e.g., Olszewska, 1985; Krhovský et al., 1992; Vyalov et al., 1996; Melinte-Dobrinescu and Brustur, 2008; Fig. 4). Studies carried out in the Moravian Outer Carpathians have shown that at the level of the cherts (originally "horizon with diatoms") intercalated with non-calcareous, dark brown-grey siliceous claystones, calcareous nannoflora is absent (Krhovský, 1981; Krhovský et al., 1992; Švábenická et al., 2007). According to these authors this horizon constitutes a record of widespread anoxia, water stratification, freshwater surface waters and high biosiliceous productivity. The foraminifer assemblages in the cherts are extremely poor. Only intercalations of mudstones or marls contain planktonic foraminifers; they belong exclusively to species of Globigerina ex gr. officinalis Subbotina, Globigerina ex gr. praebulloides Blow and the genus Turborotalia Cushman et Bermúdez (Olszewska, 1985).

Abundant fish remains have been found in the Dynów Marls (Kotlarczyk et al., 2006; Bieńkowska-Wasiluk, 2010) as well as in coeval deposits in both the Moravian (Brzobohatý, 1981; Gregorová, 1997, 2011; Prrikryl, 2013) and Romanian Carpathians (Jonet, 1947, 1958; Ciobanu, 1977). At some localities in the Polish Carpathians e.g., Wola Czudecka, Straszydle, the Dynów Marls are intercataled with peculiar marl laminae or laminated marls that commonly contain well-preserved fish skele- tons (Kotlarczyk et al., 2006; Bieńkowska-Wasiluk, 2010). These laminae and marls are assumed to be pelagic sediments and/or deposits of low-concentration turbidity currents (Bieńkowska-Wasiluk, 2010). The presence of organic matter and well-preserved fish skeletons indicate anoxic conditions below and above the sea floor.

The Dynów Marls were first described from the Skole Nappe, Polish Outer Carpathians by Kotlarczyk (1979). The origin of the Dynów Marls is supposed to be the result of the activity of submarine fans and bottom currents, and/or deposition from low-concentration turbidity currents (Kotlarczyk and Leśniak, 1990; Kotlarczyk et al., 2006). Thus far, equivalents of the Dynów Marls have been recognized and documented (under the name Dynów Marlstones) in the Alpine Foreland Basin (German and Austrian Molasse Basin) and along nearly the entire Carpathian Flysch Belt (Kotlarczyk and Leśniak, 1990; Krhovský et al., 1992, 2001; Nagymarosy and Voronina, 1992; Rögl et al., 2001; Schulz et al., 2004; Švábenická et al., 2007; Garecka, 2012; Fig. 4). Although the Dynów Marls has been used as a regional stratigraphic marker between various tectonic units and facies since the middle of the 20th century, its formal definition has not yet been proposed.

The biostratigraphic framework of the Dynów Marls unit is based largely on its characteristic calcareous nannofossils, in particular the endemic Paratethyan species Reticulofenestra ornata Müller and its explosive bloom, which is evidence of extreme ecological conditions, probably very low salinity and/or high nutrient levels (Veselov and Lul'eva, 1980; Krhovský, 1981; Krhovský et al., 1992; Melinte, 2005; Švábenická et al., 


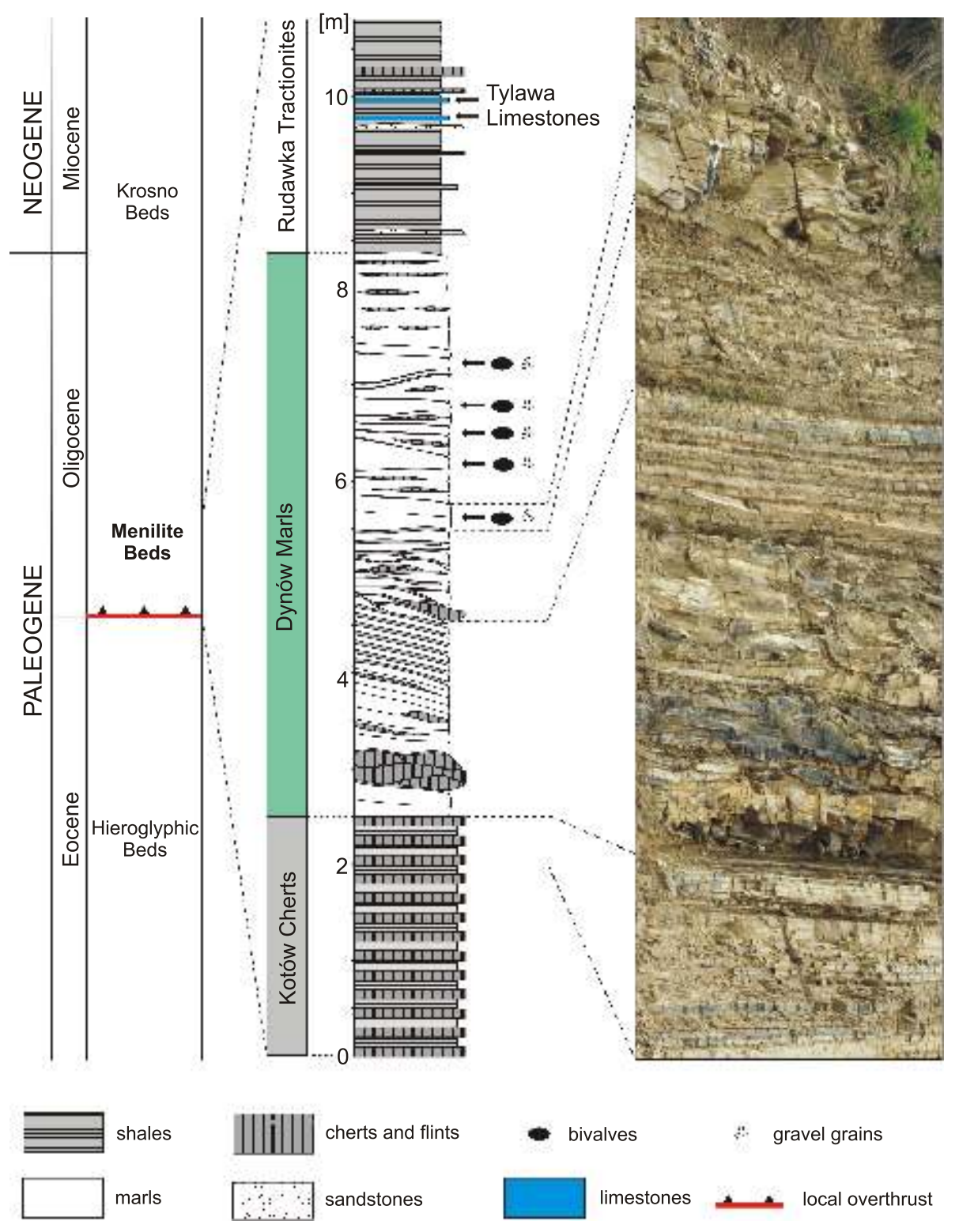

Fig. 3. The lithologic succession of the Menilite Beds at the Jabłonica Polska 2 site indicating the position of bivalve fossils

Details of units distinguished within the Menilite Beds are given in the text (see Fig. 2 for location)

2007; Melinte-Dobrinescu and Brustur, 2008). In general, the nannoplankton diversity is low but indicative of the nannoplankton Sphenolithus distentus Zone NP23 (Müller, 1970; Veselov and Lul'eva, 1980). The calcareous nannofossils from the Dynów Marls of the Skole Nappe yielded Reticulofenestra ornata Müller and Transversopontis fibula $\mathrm{Ge}$ a, which is characteristic of the lowermost NP23 Zone (Garecka, 2012). The low-diversity nannoplankton flora dominated by Reticulofenestra ornata Müller with occasional occurrences of Transversopontis fibula Ge a, T. latus Müller, Braarudosphaera bigelowi (Gran et Braarud) and Orthozygus aureus (Stradner), typical euryhaline forms, is best documented through the Lower Solenovian carbonate-rich facies of the Euxino-Caspian Basin System of the Paratethys and described as a characteristic Polbinian-type nannoflora (Veselov and Lul'eva, 1980; Andreyeva-Grigorovich, 1981; Nagymarosy and
Voronina, 1992; Fig. 5). This very poor assemblage of Polbinian-type nannoflora yielding only Reticulofenestra ornata, Transversopontis fibula and/or T. latus was documented in several exposures of the Dynów Marls in the Silesian Nappe (Nagymarosy and Voronina, 1992), in the Molasse Basin in Austria and Germany (Krhovský et al., 2001; Rögl et al., 2001; Schulz et al., 2004), and in the Transylvanian Basin (Rusu, 1988; Rusu et al., 1996; Melinte-Dobrinescu and Brustur, 2008). In the Paleogene Hungarian Basin, apart from the Polbinian-type nannoflora, very rare stenohaline elements including the index species of the NP23 Zone, Sphenolithus distentus Bramlette et Wilcoxon have been identified (Nagymarosy and Báldi-Beke, 1988). Thus, the Reticulofenestra ornata-Transversopontis fibula assemblage offers an excellent correlation tool of high stratigraphic fidelity in the Lower Oligocene and was successfully applied within Paratethys. 


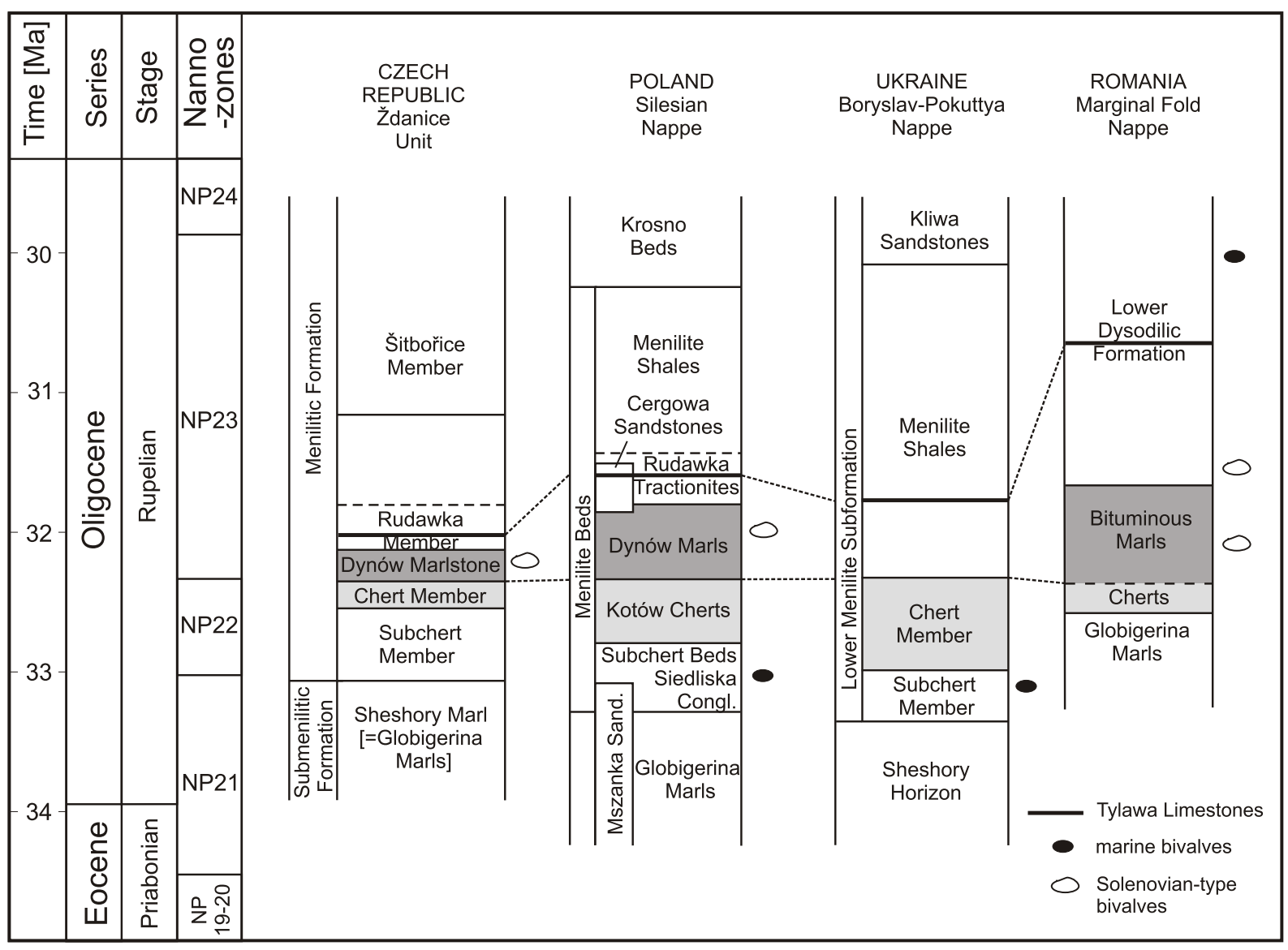

Fig. 4. Correlation of the Lower Oligocene deposits yielding the molluscan fauna in the Ždanice Unit (after Krhovský et al., 1992), the Silesian Nappe (after Kotlarczyk et al., 2006), the Boryslav-Pokuttya Nappe (after Gruzman, 1990) and the Marginal Fold Nappe (after Rusu, 1999; Melinte-Dobrinescu and Brustur, 2008)

\section{JABŁONICA POLSKA SITES}

Bivalve faunas have been found in two local quarries about $500 \mathrm{~m}$ north of Jabłonica Polska (Fig. 2). The distance between the quarries is $1.5 \mathrm{~km}$. Detailed fieldwork in these exposures was undertaken in 2009 also by the senior authors (BS and SVP) and the collection of bivalves was created for the Polish Academy of Sciences Museum of the Earth in Warsaw. In both Jabłonica Polska quarries (JP1: GPS N 4942.6526', E $21^{\circ} 54.1269^{\prime}$ and JP2: GPS N 49 $42.262^{\prime}$, E 21 $\left.{ }^{\circ} 54.879^{\prime}\right)$ the same bivalve-bearing sequence was accessible, but in the eastern quarry (JP2) the Oligocene sequence (Figs. 3 and 6) is better exposed.

The section at Jabłonica 2 attains a thickness of $12.0 \mathrm{~m}$ (Fig. 3) and begins with the Kotów Cherts represented by the $2.5 \mathrm{~m}$ thick succession of brown cherts intercalated with siliceous shales. The base of the Kotów Cherts level is not exposed. The overlying Dynów Marls, about $6 \mathrm{~m}$ thick, are represented mainly by marls with occasional lenticular chert levels. Most of the marl layers are structureless; some of them display normal grading. Common are irregular bases and tops of marl layers and associated cherts, resulting in lenticular beds that are intercalated with shales and less lithified marls (Fig. 6B, C). Scattered bivalve shells and moulds occur only in the upper part of the unit (Figs. 3 and 6). The diagenetic processes of aragonite dissolution strongly influenced the quality of shell preservation (Fig. 7). The bivalves occur in marls containing additionally lithoclasts, mainly quartz gravel (Fig. 7D, E), and fish re- mains such as scales and bones. Most of them are indeterminate vertebrae and bones of heads of teleost fishes. Among the fish material representatives of five families have been detected: Cetorhinidae Gill, Centrophoridae Bleeker, Clupeidae Cuvier, Merluccidae Gill and Trichiuridae Rafinesque. Study of their taxonomy was made by a younger author (MB-W). These gravelly marls are matrix-supported, disorganized, of irregular thickness and with distinct erosional bases that indicate origin as debris flows. The Dynów Marls unit is followed by the Rudawka Tractionites unit, about $2 \mathrm{~m}$ thick, composed predominantly of shales and sandstones. In the upper part of this unit two thin layers of laminated limestones have been observed. These limestones reflect calcareous nannoflora blooms (Krhovský, 1981; Haczewski, 1989) and are distinguished as the Tylawa Limestones and considered as a regional marker horizon (e.g., Kotlarczyk et al., 2006; Ciurej and Haczewski, 2012).

\section{MATERIAL AND METHODS}

The material available for the present study consists entirely of specimens gathered from two quarries (JP1 and JP2) by the authors during fieldwork between 2007 and 2009. The field observations showed that the bivalve fauna occurs only in the upper part of the Dynów Marls. Sampled levels at the Jabłonica Polska 2 site are marked in Figures 3 and 6 . The bivalve specimens were separated from dark brown siliceous marls. Specimens were whitened with $\mathrm{MgO}$ and photographed with a Nikon 


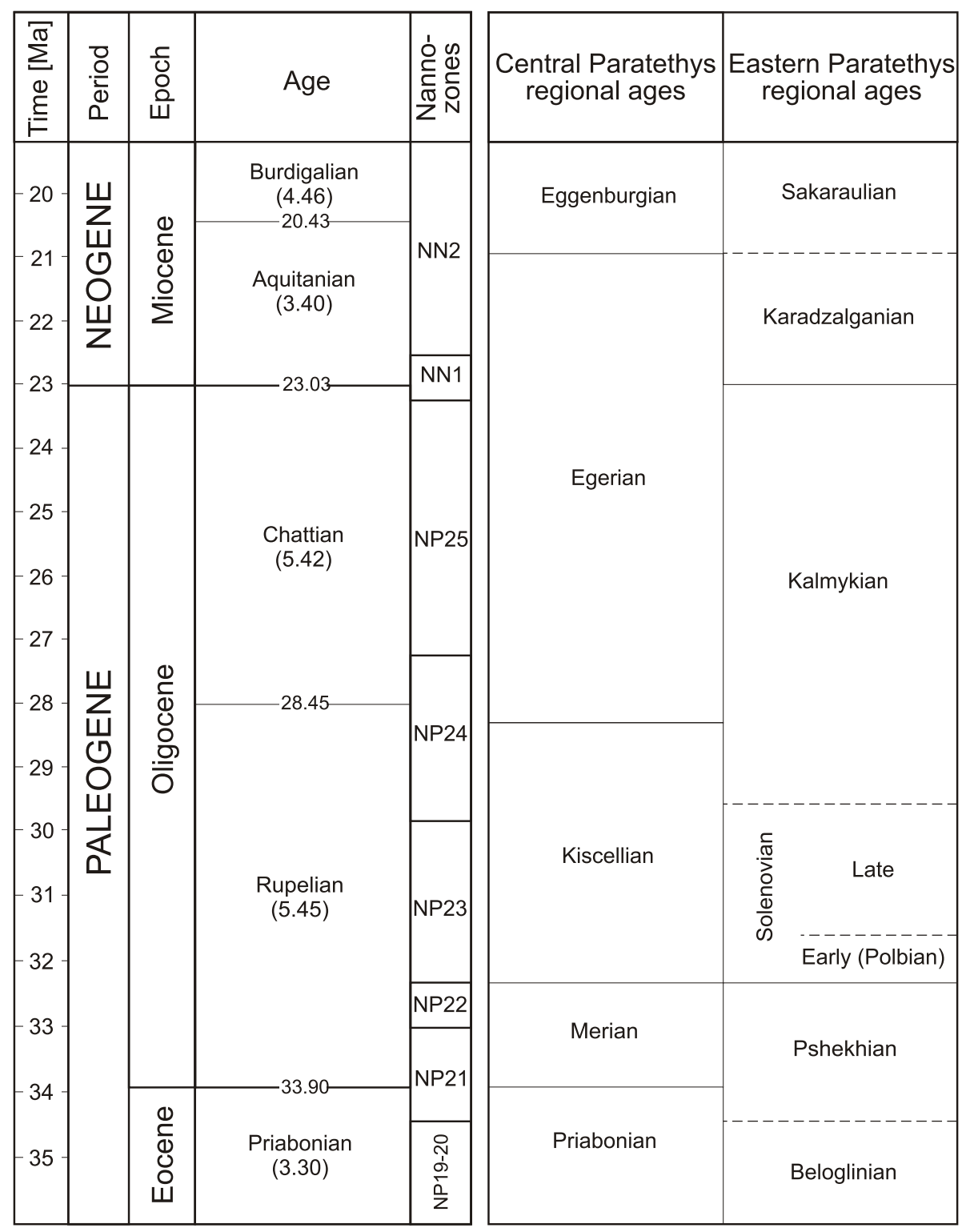

Fig. 5. Time framework of the Late Eocene to Early Miocene after the International Stratigraphic Chart 2013

Calcareous nannoplankton standard zones are those of Martini (1971); the Central Paratethys ages are adopted from Rusu et al. (1996), and Piller et al. (2007); Eastern Paratethys ages follow Popov et al. (2004, 2009b)

$D$-50 digital camera. The fossils are generally unfavourably preserved and the shell material is partly dissolved (Fig. 7). The specimens are frequently incomplete and/or articulated, so in many cases it was not possible to study the inside of the shell. Despite many problems - valves embedded in the rock, fragmented material, imprints and moulds of shell interiors - the fauna allows palaeoecological interpretation.

The shell material has been compared with several historical collections. In preparing the present report, we had access to: (1) a large collection of Solenovian (mid Early Oligocene; for its age see Fig. 5) bivalves from South Russia, Georgia and Kazakhstan collected by Merklin $(1961,1974)$, Popov and Titova (1982), Voronina and Popov (1984) and Popov et al. (1993b), and a reference collection of Solenovian bivalves from
Ukraine, housed in the Borissiak Paleontological Institute, Russian Academy of Sciences in Moscow (PIN); (2) the Hamrat Collection kept at the Hungarian Natural History Museum in Budapest illustrated, in part, by Báldi (1986); (3) a large collection of Rupelian bivalves from Transylvania gathered by Moisescu (1972) and presented to the Grigore Antipa National Museum of Natural History in Bucharest, and (4) specimens of Solenovian bivalves collected by Rusu $(1977,1988)$ and stored in the Geological Institute in Bucharest.

The Carpathian bivalve material documented herein is all deposited at the Polish Academy of Sciences Museum of the Earth in Warsaw, Poland (abbr. MZ) under the catalogue numbers MZ VIII MI 3865 - MZ VIII MI 3891 and MZ VIII MI-3904 MZ VIII MI-3954. 

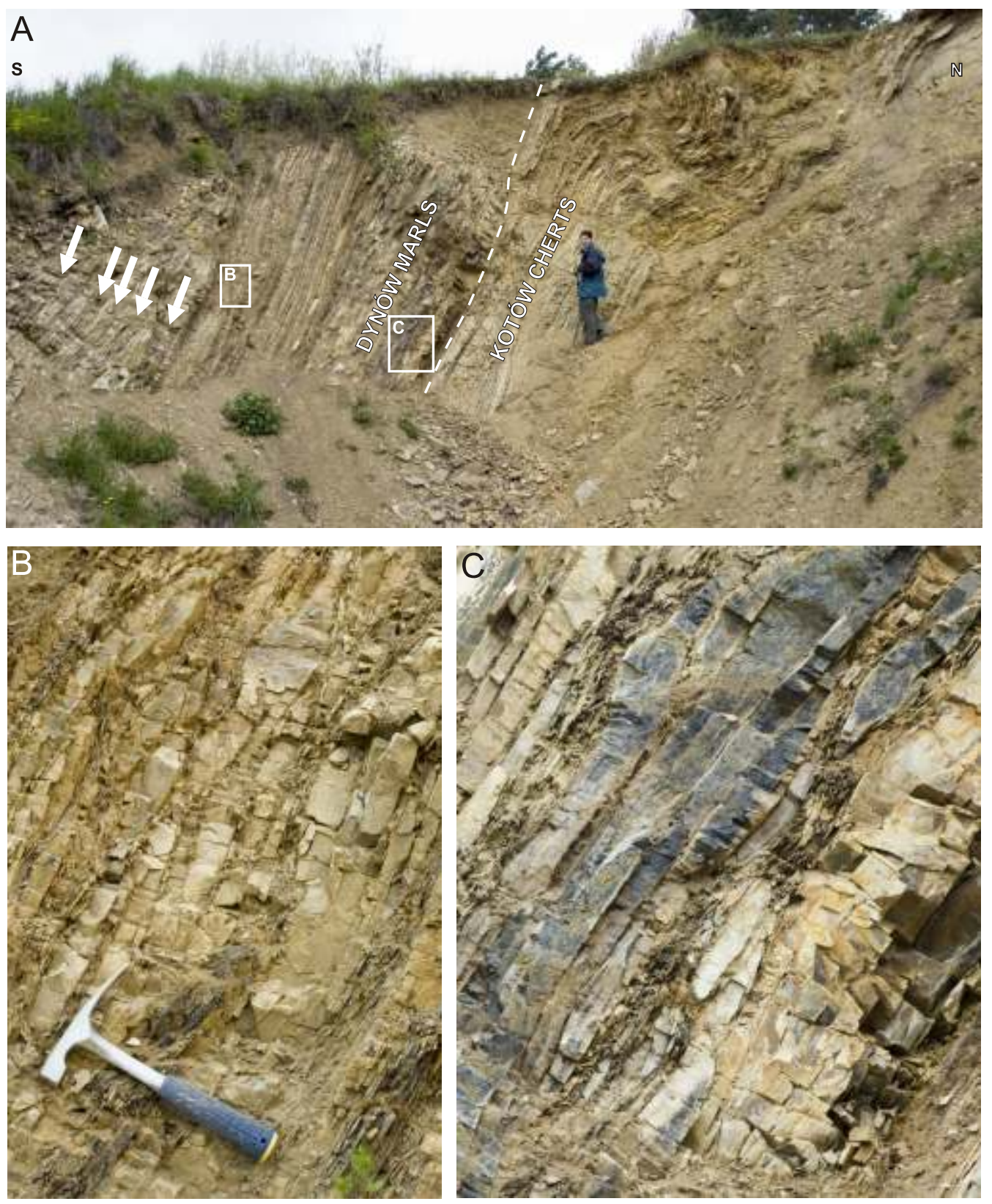

Fig. 6. Exposure of the Menilite Beds at Jabłonica Polska 2

A - eastern wall of the abandoned small quarry near Jabłonica Polska; arrows indicate bivalve-bearing levels; B - marl lenses in calcareous shales, $1 \mathrm{~m}$ below marls with crushed molluscan shells;

C - lower part of the Dynów Marls with lenticular cherts

\section{RESULTS}

FAUNAL COMPOSITION

One hundred twenty bivalve specimens were collected in the Dynów Marls during this study. The bivalve fauna from the Jabłonica Polska 1 site includes nine species, while the fauna collected in the Jabłonica Polska 2 site is represented by thirteen species. Some specimens are attributed only to generic level due to unfavourable preservation. The taxonomic composition of the bivalve fauna from both Jabłonica Polska sites is summarized in Table 1. A total of 16 bivalve species have been identified that represent six genera belonging to five families.
Among these, species belonging to the cardiid genus Cerastoderma Poli and the myid genus Janschinella Merklin are by far the most abundant elements.

Based on the collections stored in the Borissiak Paleontological Institute RAS and relevant literature (Merklin, 1961, 1974; Nossovsky, 1962; Veselov and Sheremeta, 1964; Rusu, 1977, 1999; Kojumdgieva and Sapundgieva, 1981; Popov and Titova, 1982; Báldi, 1984, 1986; Kazakhashvili, 1984; Voronina and Popov, 1984; Popov et al., 1985, 1993b; Rusu et al., 1996; Schultz, 2003, 2005; Íslamoğlu et al., 2010), data on the stratigraphic range and palaeogeographic distribution of each taxon identified are briefly presented below.

Cerastoderma serogosicum (Nossovsky) (Figs. 7A and 8A, B). The species Cardium serogosicum was created by 

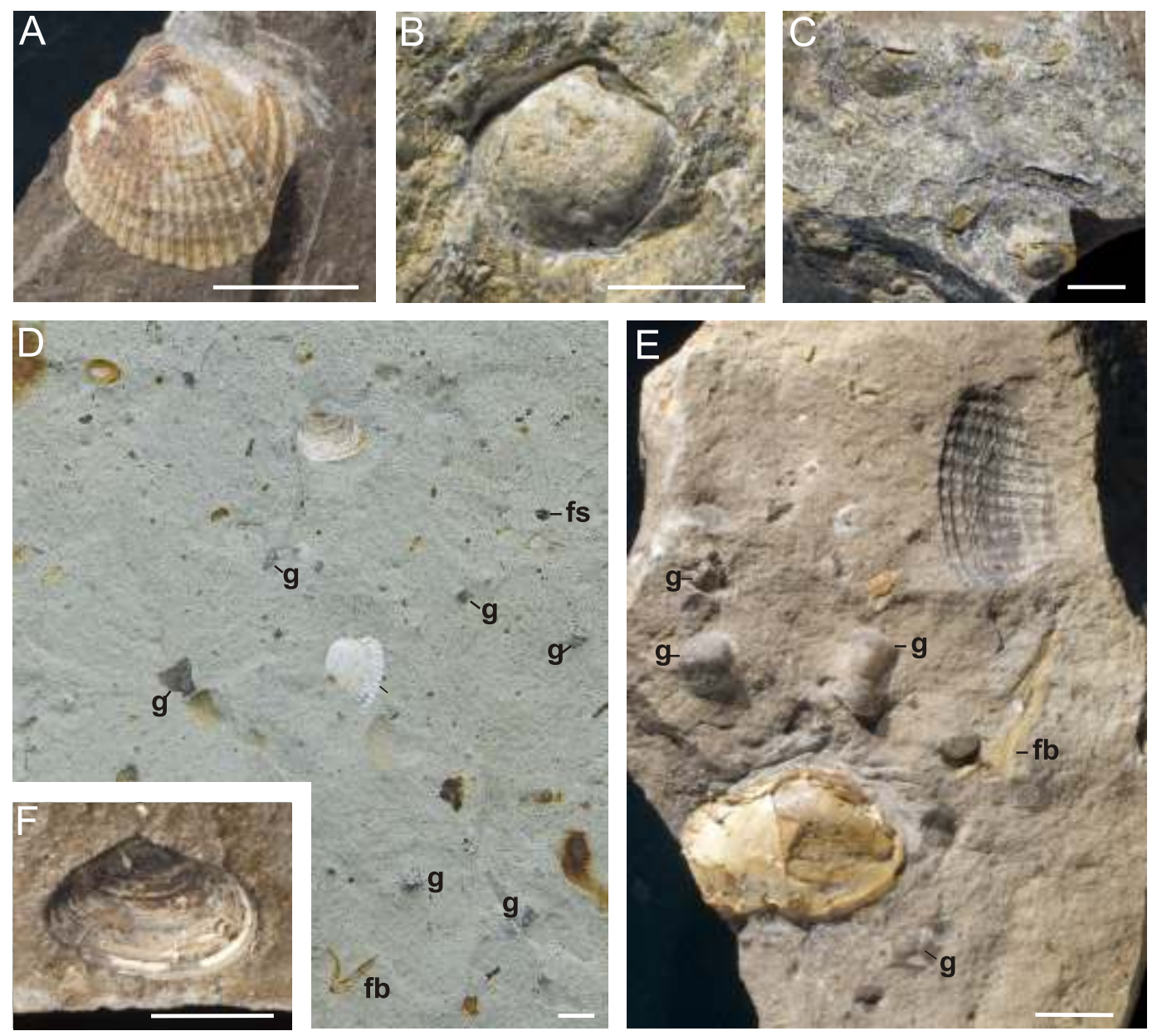

Fig. 7. Preservation state of bivalve shells from the Dynów Marls

A - Cerastoderma serogosicum (Nossovsky, 1962), exterior of left valve (MZ VIII MI-3877/1); B - Lenticorbula cf. sokolovi (Karlov, 1962), internal mould of right valve (MZ VIII MI-3871/1); C - Lentidium cf. ustjurtense Merklin, 1974, internal mould of two right valves (MZ VIII MI-3873); D - Lentidium ustjurtense Merklin, 1974, exterior of left valve (top) and fragment of Cerastoderma sp. (middle) with quartz grains (g), various undetermined fragments of fish-bones (fb) and fish scales (fs); E - Janschinella vinogrodskii (Merklin, 1961), articulated shell, view of left valve (MZ VIII MI-3891/5) and imprint of fragment Korobkoviella sp. valve (top right) with quartz grains (g) and various undetermined fragments of fish-bones (fb); F - Lentidium cf. ustjurtense Merklin, 1974, exterior of right valve (MZ VIII MI-3873); scale bars 5 mm; A, E, F - Jabłonica Polska 2; B-D - Jabłonica Polska 1

Nossovsky (1962: 30, pl. 5, figs. 1-4) on the basis of material found in core material of the Nizhniy Serogozy borehole in the region of Kherson, Ukraine. Research on Lower Oligocene successions has shown Cerastoderma serogosicum to be widespread throughout the Paratethys and moderately abundant in different basins. Its occurrence in the Euxino-Caspian Basin System has been documented in different localities of the Upper Solenovian Serogozy Suite of the Black Sea Region, Ukraine (Nossovsky, 1962; Veselov and Sheremeta, 1964; Popov et al., 1993b), in the Ezerovo Fm. of the High Thracian Basin, Bulgaria (Kojumdgieva and Sapundgieva, 1981), in the Solenovian Otskhe Beds and the Tskhruta-Tsakhana Suite of Akhaltsikhe, in the Avchaly Suite of Kartli and the Congeria Beds of Guria in Georgia (Merklin, 1974; Voronina and Popov, 1984; Popov et al., 1993b), and in both the Solenovian South Mangyshlak Suite of the Mangyshlak Peninsula and the Tamdy Suite of the Northern Ustyurt Plateau in Kazakhstan (Merklin, 1974; Popov et al., 1985, 1993b). It is also recorded in the Kiscellian Ileanda and Creaca formations in Transylvania, Romania (Rusu, 1977, 1988; Rusu et al., 1996) and in both Bitumi- nous Marls and Lower Dysodilic Fm. of the Outer Carpathians in Romania (Rusu, 1999).

Korobkoviella kiktenkoi (Merklin). The species Cerastoderma (Korobkoviella) kiktenkoi was established by Merklin (1974: 98, pl. 39, figs. 7-11) based on fossils found in the Bolshaya Kostromka borehole in the Black Sea Region. This species designated by Merklin (1974: 97-98) as a type species of the subgenus Cerastoderma (Korobkoviella) is restricted to the Oligocene Paratethys. Up to now it has been reported from the Solenovian Otskhe Beds of Akhaltsikhe and the Solenovian Urbnisia Beds of the Avchaly Suite in Georgia (Popov and Titova, 1982; Popov et al., 1993b) and from the Lower Tsraudon Suite of North Ossetia-Alania in the Russian Federation (Popov et al., 1993b). Its occurrence in the Lower Kiscellian of Austria was only presumed: in the opinion of Schultz (2003: 562-563), Austrian specimens described as Cardium lipoldi represent Korobkoviella kiktenkoi. In contrast to the statement of Schultz (2003), the present authors regard Korobkoviella kiktenkoi (Merklin, 1974) and K. lipoldi (Rolle, 1858) as different, albeit closely allied, species. The latter was created by Rolle 
Table 1

List of bivalve species from two quarries near the Jabłonica Polska vicinity showing number of specimens found in each quarry

\begin{tabular}{|c|c|c|c|}
\hline Family & Species & JP1 & JP2 \\
\hline Lucinidae Fleming, 1823 & Loripes sp. & 2 & \\
\hline Cardiidae Lamarck, 1828 & $\begin{array}{l}\text { Cerastoderma serogosicum (Nossovsky, 1962) } \\
\text { Cerastoderma cf. serogosicum (Nossovsky, 1962) } \\
\text { Cerastoderma sp. } 1 \\
\text { Cerastoderma sp. } \\
\text { Korobkoviella cf. ahalcikhensis Popov, 1982 } \\
\text { Korobkoviella cf. kiktenkoi (Merklin, 1974) } \\
\text { Korobkoviella sp. }\end{array}$ & $\begin{array}{l}6 \\
1 \\
3 \\
\\
1 \\
3\end{array}$ & $\begin{array}{c}5 \\
2 \\
3 \\
14 \\
2 \\
2\end{array}$ \\
\hline Corbulidae Lamarck,1818 & $\begin{array}{l}\text { Lenticorbula sokolovi (Karlov, 1962) } \\
\text { Lenticorbula slussarevi (Merklin, 1974) } \\
\text { Lenticorbula mefferti Titova, 1982 } \\
\text { Lenticorbula sp. } 1 \\
\text { Lenticorbula sp. } 2 \text { [? subtriangula(Moisescu, 1962)] } \\
\text { Lentidium ustjurtense Merklin, 1974 } \\
\text { Lentidium cf. ustjurtense Merklin, 1974 } \\
\text { Lentidium cf. ianischewskii (Ruchin, 1935) } \\
\text { Lentidium aff. leonovi Titova, } 1982\end{array}$ & $\begin{array}{l}3 \\
3 \\
4\end{array}$ & $\begin{array}{l}2 \\
1 \\
2 \\
3 \\
1 \\
9 \\
8 \\
4\end{array}$ \\
\hline Myidae Lamarck,1809 & $\begin{array}{l}\text { Janschinella vinogrodskii (Merklin, 1961) } \\
\text { Janschinella cf. vinogrodskii (Merklin, 1961) }\end{array}$ & $\begin{array}{l}6 \\
3\end{array}$ & 17 \\
\hline Dreissenidae Gray, 1840 & Mytilopsis kochi (Andrussow, 1900) & & 2 \\
\hline \multicolumn{2}{|l|}{ Number of specimens } & 42 & 78 \\
\hline
\end{tabular}

JP1 - Jabłonica Polska 1 site; JP2 - Jabłonica Polska 2 site

(1858: 25-26, pl. 2, figs. 8-10) based on material found in the Eocene and/or Oligocene coal-bearing strata of the Southern Karavanke Mts., Slovenia and distinguished by him as the Sotzka-Schichten (Socka Beds). Based on its calcareous nannofloral content Báldi (1984) correlated the Socka Beds with the nannoplankton zone NP 23 (Middle Kiscellian). More recently, on the basis of planktonic and benthic foraminifers detected in the Socka Beds Cimerman et al. (2006) referred this unit to the Priabonian (Late Eocene). The occurrence of Korobkoviella lipoldi has been documented in the middle Tard Clay of the Paleogene Hungarian Basin, Hungary (Báldi, 1984, 1986), in the Ezerovo Fm. of the High Thracian Basin, Bulgaria (Kojumdgieva and Sapundgieva, 1981), in both Bizuşa and lleanda formations in Transylvania, Romania (Rusu, 1977; Rusu et al., 1996) and from Lower Oligocene deposits of the Outer Carpathians: the Dynów Marls at Křepice, in the Czech Republic (Čtyroký, 1991) and both Bituminous Marls and Lower Dysodilic Fm. at Piatra Neam in Romania (Rusu, 1999).

Korobkoviella ahalcikhensis Popov (Fig. 8C). The species was introduced by Popov (Popov and Titova, 1982: 43, pl. 5, figs. 22, 23) based on specimens found in the Solenovian deposits at the village of Chvinta, near the town of Akhaltsikhe in Georgia. It has been also detected in several localities of the Solenovian Otskhe Beds of Akhaltsikhe and Urbnisia Beds of the Avchaly Suite of Georgia (Popov and Titova, 1982). The available evidence suggests that in other parts of the Paratethys Korobkoviella ahalcikhensis is rarely encountered. It is only known from the Solenovian Tsraudon Suite of North Ossetia-Alania in the Russian Federation (Popov et al., 1993b).

Lenticorbula sokolovi (Karlov) (Figs. 7B and 8F-H). Amongst Lenticorbula species recognized within the Oligocene Paratethyan fauna, Lenticorbula sokolovi is relatively common.
The species Lentidium sokolovi was created by Karlov (1962: 104, pl. 1, figs. 1-8) on the basis of material documented within the Serogozy Suite in the core of the Novo-Nikolayevka borehole in the Black Sea Region. It is established that Lenticorbula sokolovi inhabited the Euxine-Caspian area since the Pshekhian (earliest Oligocene) and persisted up to the terminal Kalmykian (latest Oligocene) (Merklin, 1974; Popov et al., 1993b). So far its oldest record throughout the Paratethys is from the Pshekhian Ashcheairyk Suite of the Northern Ustyurt Plateau in Kazakhstan (Merklin, 1974). Its occurrence in the Solenovian has been documented in the Tsraudon Suite of North Ossetia-Alania in the Russian Federation (Popov et al., 1993b), in the Congeria Beds of Guria, the Otskhe Beds and Tskhruta Suite of Akhaltsikhe and the Avchaly Suite of Kartli in Georgia (Merklin, 1974; Popov et al., 1993b) as well as in the Tamdy Suite of the Northern Ustyurt Plateau, Kazakhstan (Merklin, 1974). Its presence is well-documented in the Ezerovo Fm. of the High Thracian Basin, Bulgaria (Kojumdgieva and Sapundgieva, 1981). The available data suggests that in the Kalmykian (Late Oligocene) of the Paratethys Lenticorbula sokolovi is rarely encountered: its youngest records are in a few localities of Kalmykian Sivash Suite of Ukraine and the Kokturnak Beds of the northern Aral Region, Kazakhstan (Merklin, 1974). Its occurrence in the Middle Kiscellian has been documented in the Bizusa Marls and Creaca Clays of the Ileanda Fm. in Transylvania, Romania (Rusu, 1977).

Lenticorbula slussarevi (Merklin). Merklin (1974: 144, pl. 48, figs. 16-22) erected the subspecies Corbula (Lenticorbula) sokolovi slussarevion the basis of the Solenovian material found in the Chilikta Suite of the northern Aral Region in Kazakhstan. The presence of this taxon is documented in several exposures of the Serogozy Suite of the Black Sea Region (Veselov and 

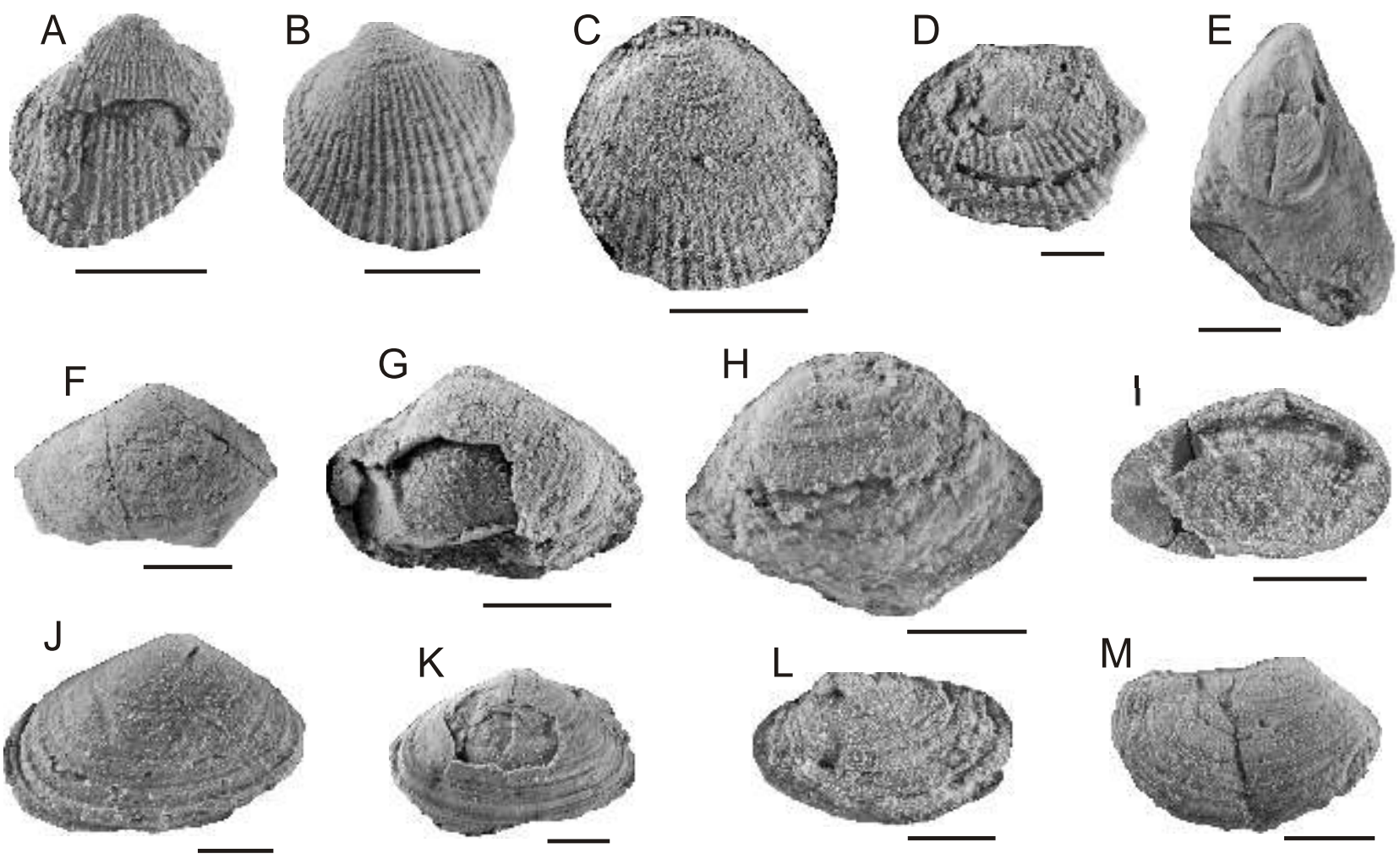

Fig. 8. Selected Early Oligocene bivalves (Solenovian-type) from the Silesian Nappe, Polish Carpathians

A, B - Cerastoderma serogosicum (Nossovsky, 1962): A - exterior of right valve (MZ VIII MI-3867), B - exterior of left valve (MZ VIII MI-3877/1); C - Korobkoviella cf. ahalcikhensis Popov, 1982, exterior of left valve (MZ VIII MI-3881/1); D - Korobkoviella sp., exterior of left valve (MZ VIII MI-3855); E - Mytilopsis kochi (Andrussow, 1900), exterior of right valve (MZ VIII MI-3883/2); F-H - Lenticorbula sokolovi (Karlov, 1962): $\mathrm{F}$ - umbonal part of right valve (MZ VIII MI-3885/2), G - right valve with partial shell preservation (MZ VIII MI-3885/1); H - exterior of right valve (MZ VIII MI-3868/3); I - Lentidium aff. leonovi Titova, 1982: interior of left valve (MZ VIII MI-3886/2); J, K - Lentidium ustjurtense (Merklin, 1974): J - rubber replica of left valve (MZ VIII MI-3888/2), K - exterior of left valve (MZ VIII MI-3888/1); L, M Janschinella vinogrodskii (Merklin, 1961): L - exterior of right valve (MZ VIII MI-3874/1), M - exterior of right valve (MZ VIII MI-3890/1); scale bars $10 \mathrm{~mm}$; A, D, L - Jabłonica Polska 1; B, C, E, F-K, M - Jabłonica Polska 2

Sheremeta, 1964, as Corbula sp.) and from the Solenovian Otskhe Beds, the Tskhruta Suite of Akhaltsikhe and the Avchaly Suite of Kartli in Georgia (Popov and Titova, 1982: 38-41, as C. subtriangula). Moreover, Lenticorbula slussarevi was previously reported from the Lower Oligocene Ezerovo Fm. of the High Thracian Basin in southern Bulgaria (Kojumdgieva and Sapundgieva, 1981, as L. sokolovi slussarevi), from the Solenovian Pinarhisar Fm. of Thrace, Turkey (Íslamoğlu et al., 2010), and from the Lower Solenovian Tsraudon Suite of North Ossetia-Alania in the Russian Federation (Popov et al., 1993b).

Lenticorbula mefferti Titova. The moderately large, well-characterized species Corbula (Lenticorbula) mefferti was introduced by Titova (Popov and Titova, 1982: 46-47, pl. 5, figs. 45-47) based on material from the Oligocene Otskhe Beds at the village of Chvinta near the town of Akhaltsikhe in Georgia. It is noteworthy that through the Paratethys Lenticorbula mefferti seems to be sparsely distributed (Popov and Titova, 1982; Kazakhashvili, 1984). Until now its specimens were known exclusively from the Solenovian deposits of Georgia: the Otskhe Beds of Akhaltsikhe (type locality), the Avchaly Suite of Kartli, and the Congeria Beds of Guria

Lentidium ianischewskii (Ruchin). This essentially Paratethyan species occurs abundantly only in the Pshekhian (lowermost Oligocene) deposits of the northern Aral Region, from where it was described by Ruchin (1935: 49, pl. 2, fig. 11), and in the Pshekhian Ashcheairyk Suite of the Northern Ustyurt Plateau in Kazakhstan (Merklin, 1974).

Lentidium leonovi Titova (Fig. 8I). The species, extremely rare in the Paratethys, has been reported mainly from the Solenovian deposits of Georgia: in the Otskhe Beds at Chvinta (the type locality), the Tskhruta Suite of Akhaltsikhe and the Avchaly Suite of Kartli (Popov and Titova, 1982; Kazakhashvili, 1984; Popov et al., 1993b). It was also found in the Serogozy Suite of the Black Sea Region, Ukraine. The specimens from the Polish Outer Carpathians ascribed to Lentidium aff. leonovi resemble very closely Lentidium leonovi, however, they differ from the latter species (see Titova in Popov and Titova, 1982: 47, pl. 5, figs. 31-33), in the shell outline: they are less elongated than the type Georgian specimens $(\mathrm{H} / \mathrm{L}$ 0.66-0.69 versus $0.44-0.57$ ) with its posterior part accounting for $66-67 \%$ of the valve length (up to $13.5 \mathrm{~mm}$ ). The anterior ridge is more distinct than on the typical form. Consequently, the Georgian and Carpathian specimens might belong to two, although closely related species. A definitive decision would require better-preserved additional Carpathian material.

Lentidium ustjurtense Merklin (Figs. 7C, D, F and 8J, K). This occurs abundantly only in the Pshekhian Ashcheairyk Suite of the northern Ustyurt Plateau in Kazakhstan, from where 
it was described (Merklin, 1974: 147, pl. 49, figs. 15-21). Its occurrence was also reported from the Middle Kiscellian lleanda Fm. in Transylvania, Romania (Rusu, 1977). The genus Lentidium de Cristofori et Jan, 1832 [=Corbulomya Nyst, 1843] shows definite boreal affinities and it is possible that Lentidium donaciforme (Nyst, 1836) recorded in the Lower Oligocene of Belgium, France and Germany (Gitton et al., 1986; Marquet et al., 2008) as well as in the basal part of the Lower Oligocene (Pshekhian) of Kazakhstan is the most probable ancestor of Lentidium ustjurtense Merklin, 1974.

Janschinella vinogrodskii (Merklin) (Figs. 7F, 8L, M). This thin-shelled species was described by Merklin (1961: 86, pl. 9, figs. 6-9) on the basis of material collected from the borehole in Bolshaya Kostromka, South Ukraine. It shows a wide distribution within the Early Oligocene Paratethys. It occurs abundantly in the Lower Solenovian Molochanskaya Suite of the Black Sea Region, Ukraine (Veselov and Sheremeta, 1964; Popov et al., 1993b), the Upper Solenovian Serogozy Suite, Ukraine (Nossovsky, 1962; Veselov and Sheremeta, 1964; Merklin, 1974) as well as in the Solenovian Suite of Ergeni in Russia (Popov et al., 1993b). The presence of Janschinella vinogrodskii is documented in the Tsraudon Suite of North Ossetia-Alania in the Russian Federation (Popov et al., 1993b) and from the Solenovian deposits of Georgia: the Otskhe Beds and the Tskhruta Suite of Akhaltsikhe, and the Avchaly Suite of Kartli (Popov and Titova, 1982; Kazakhashvili, 1984; Voronina and Popov, 1984; Popov et al., 1993b). It was reported (as Janschinella melitopolitana) from the Middle Kiscellian of Austria (Schultz, 2005), the middle Tard Clays of the Hungarian Paleogene Basin (Báldi, 1984,1986), the lleanda Fm. in Transylvania, Romania (Rusu, 1977) and the Ezerovo Fm. of the High Thracian Basin in Bulgaria (Kojumdgieva and Sapundgieva, 1981), in the Pinarhisar Fm. of Thrace in Turkey (Íslamoğlu et al., 2010). Moreover, the presence of Janschinella vinogrodskii is documented in the Upper Pshekhian Varkhan Beds of Akhaltsikhe, Georgia (Popov et al., 1993b). The species Janschinella vinogrodskii (Merklin) has never been reported from any other Carpathian localities (Čtyroký, 1991; Rusu, 1999) whereas both the Bituminous Marls and the Lower Dysodilic Fm. of the Romanian Outer Carpathians so far have yielded specimens of Janschinella garetzkii (Merklin), the type species of the genus Janschinella by original designation (see Merklin, 1961: 84-85, pl. 9, figs. 6-9).

Mytilopsis kochi (Andrussow) (Fig. 8E). Andrussow (1900: 75-76, pl. 1, figs. 8-11) described the species Congeria kochi on the basis of material collected from the Oligocene deposits of the Almash Basin in Transylvania. The Transylvanian specimens from the Cetate Beds in the Almash Basin ascribed by Moisescu (1964) as Congeria tenuissima are, in the opinion of Kojumdgieva and Sapundgieva (1981), indistinguishable from Congeria kochi and should be treated as a single species named kochi, according to the priority rule. The species Mytilopsis kochi was known from the Upper Oligocene Ezerovo Fm. of the High Thracian Basin in Bulgaria (Kojumdgieva and Sapundgieva, 1981). It was also reported (as Congeria tenuissima, Moisescu) from both the Pshekhian Karatuban and Varkhan Beds of Akhaltsikhe in Georgia and from the Solenovian Tsraudon Suite of North Ossetia-Alania in the Russian Federation as well as from the Solenovian Otskhe Beds and Tskhruta Suite of Akhaltsikhe, the Avchaly Suite of Kartli and the Congeria Beds of Guria in Georgia (Popov and Titova, 1982). Its occurrence is also known from the Upper Oligocene (Kalmykian) Kokturnak Beds of the northern Aral Region in Kazakhstan (Merklin, 1974; Popov et al., 1993a).

\section{FAUNAL AFFINITIES}

With respect to taxonomic composition, the studied assemblages include mainly species representing typical index-taxa for the Solenovian stage of the Eastern Paratethyan (Voronina and Popov, 1984, 1985; Popov et al., 1985, 1993b). The Solenovian bivalve faunas are characterized by a small number of families, poor generic composition and the absence of fully marine stenohaline taxa. It is dominated by endemic taxa belonging to euryhaline bivalve families such as the Cardiidae Lamarck, Cultellidae Davies, Dreissenidae Gray, Rzehakiidae Korobkov, Myidae Lamarck, Cyrenidae Gray and Corbulidae Lamarck, of which the family Cardiidae reaches particularly high taxonomic diversity. It embraced predominantly the extinct Oligocene Paratethyan genera Bessia Kojumdgieva et Sapungieva, Korobkoviella Merklin and Merklinicardium Popov and endemic species of the genera Parvicardium Monterosato and Cerastoderma Poli of which modern representatives are able to adapt to environments with a wide range of salinity. Other endemic genera occurred throughout the Paratethys: Ergenica G. Popov and Urbnisia Goncharova (Rzehakiidae, albeit according to the World Register of Marine Species these genera should be included within the family Veneridae), Jans chinella Merklin (Myidae) and Lenticorbula Merklin (Corbulidae). Moreover, the presence of the genus Loripes Poli (Lucinidae), and endemic species of the genera Siliqua Megerle von Mühlefeld (Cultellidae), Mytilopsis Conrad (Dreissenidae), Polymesoda Rafinesque (Cyrenidae) and Lentidium Cristofori et Jan (Corbulidae) suggest environmental conditions characterized by a wide range of physical-chemical parameters such as ion composition and water salinity.

Close inspection of Table 1 shows that a number of species have stratigraphic/ecologic significance. The assemblages studied show strong affinities with those documented in the Solenovian strata of the Euxino-Caspian Basin System of the Paratethys. The species Cerastoderma serogosicum (Nossovsky), Lenticorbula sokolovi (Karlov), Lenticorbula slussarevi (Merklin) and Janschinella vinogrodskii (Merklin) have the widest geographic distribution within the Paratethys and are most common in Solenovian strata that were deposited predominantly in shallow-marine and brackish-waters (Voronina and Popov, 1984, 1985; Popov et al., 1993a, b; Popov and Studencka, 2015). Of the four species mentioned above, the occurrence of three is limited to the Solenovian and Lower Kiscellian (dated NP23); only Lenticorbula sokolovi also occurs in the Pshekhian (dated NP22). The occurrence of five species: Cerastoderma serogosicum (Nossovsky), Lenticorbula sokolovi (Karlov), Lentidium ustjurtense Merklin, Janschinella vinogrodskii (Merklin) and Mytilopsis kochi (Andrussow) has been documented in both the Solenovian of the Euxine-Caspian Basin System and the Lower Kiscellian of the Paleogene Hungarian and Transylvanian basins (Merklin, 1974; Rusu, 1977; Kojumdgieva and Sapundgieva 1981; Báldi, 1984, 1986; Popov et al., 1985, 1993b). The present research shows the first occurrence of Korobkoviella kiktenkoi (Merklin), Korobkoviella ahalcikhensis Popov and Lenticorbula mefferti Titova in the Lower Oligocene beyond the Euxine-Caspian Basin System.

\section{PALAEOENVIRONMENTAL CONSIDERATIONS}

It is assumed that environmental features such as salinity, stratification of water column and conditions at the basin bottom of the Solenovian-Early Kiscellian Paratethys were similar to 
those of the Holocene Black Sea (e.g., Rusu, 1977, 1988; Rögl, 1999; Báldi, 1984; Schulz et al., 2005). Thus, it is of some interest to compare the bivalve faunas of the two basins. The most comprehensive study concerning the latter fauna was done by Nevesskaja (1961, 1965), who investigated a series of about 70 borehole sections (each ca. $3 \mathrm{~m}$ long) in both the Black and Azov seas which allowed recognition of biotic events and reconstruction of environmental changes during the latest Quaternary. Much interest was focused on the ecological requirements of particular species as a clue to understand the composition of the modern Black Sea fauna. Initially, five bivalve assemblages were recognized (Nevesskaja, 1961). Their composition changes significantly through the sections studied, reflecting changes in salinity. The lower assemblage, characterized by Dreissena polymorpha (Pallas), Monodacna pontica (Eichwald) and Adacna euxinica Nevesskaja shows strong affinities to the modern Caspian fauna. The second one suggests the possibilities of a marine connection towards the Mediterranean: the Caspian-type fauna was accompanied by very rare euryhaline taxa, such as Cerastoderma glaucum (Bruguière), Abra segmentum (Récluz) and Lentidium mediterranum (da Costa). In the middle assemblage, the dominance of the three species mentioned above, which are extremely tolerant of salinity variations, is observed (C. glaucum: $2.5-35 \%$; $A$. segmentum: 4-45\%; L. mediterranum: 7-18\%o) together with other brackish water-tolerant taxa i.e. Mytilaster lineatus (Gmelin) and Parvicardium exiguum (Gmelin). Notably, the abundance of Dreissena polymorha decreases largely while Monodacna pontica and Adacna euxinica are missing. The next, fourth assemblage with Cerastoderma glaucum accessory and dominant Mytilus galloprovincialis Lamarck, Spisula subtruncata (da Costa) and Chamelea gallina (Linneaus), indicates marine influence. Establishment of more stable marine conditions profoundly influenced the composition of the latter assemblage. It is characterized by the dominance of Lucinella divaricata (Linnaeus), Gouldia minina (Montagu), Pitar rudis (Poli) and by accompanying taxa, such as Moerella donacina (Linnaeus) and Irus irus (Linnaeus).

The reconstruction of environmental changes based on bivalve assemblages presented by Nevesskaja $(1961,1965)$ is in good agreement with the investigation of calcareous nannoplankton assemblages from the Holocene deposits of the NW Black Sea. They also suggest progressive increase of salinity: from fresh-water lacustrine conditions around $7 \mathrm{kyr}$ BP to more stable marine conditions, with average salinity surface water of 17-18\% (Giunta et al., 2007; Oaie and Melinte-Dobrinescu, 2012).

According to the systematic description by Nevesskaja (1965), at least 43 species, representing 22 families, are present in the modern Black Sea fauna. The family Cardiidae Lamarck is the most diverse and abundant group, followed by the Mytilidae Rafinesque and Semelidae Stoliczka. The modern Black Sea bivalve fauna demonstrates essentially Mediterranean affinities, showing as high as $80 \%$ identity at the species level. In comparison with the Mediterranean faunas, however, it is characterized by euryhaline taxa that are able to adapt to mesohaline conditions. From among 38 species which are in common with the Mediterranean, 19 species do not survive at salinities <17-18\%. Among them Modiolula phaseolina (Philippi), Lucinella divaricata (Linnaeus), Parvicardium papillosum simile Milaschevitsch, Gouldia minima (Montagu), Pitar rudis (Poli) and Gastrochaena dubia (Pennant) are abundant. Significantly, most of these species are represented by specimens smaller than those from the Mediterranean, suggesting a sub-optimal environment. Whilst large specimens of three spe- cies easily tolerating salinity variations - Cerastoderma glaucum, Abra segmentum and Lentidium mediterranum - occur predominantly in areas located close to river mounths.

All the above data indicate that the modern fauna of the Black Sea developed by migration of species from the Mediterranean whereas the Solenovian-Early Kiscellian Paratethys fauna has been inherited from the previous earliest Rupelian Northern Peri-Tethys as a result of the closure of both the North Sea and Proto-Mediterranean seaways. Contrary to the modern Black Sea bivalve fauna that is characterized by a low level of endemism and a high percentage of species in common with the Mediterranean, those populating the Early Solenovian-Early Kiscellian Paratethys show highly endemic character. Additionally, the Early Solenovian-Early Kiscellian Paratethys fauna contains significantly fewer families as compared to the Recent Black Sea bivalve fauna (8 versus 22). The bivalve genera restricted to the Paratethys constitute $>50 \%$ of the Early Solenovia-Early Kiscellian fauna. Extremely low diverse bivalve assemblages (frequently composed of three to four species) together with a specific ostracod association (Nikolaeva, 1998; Popov et al., 2002; Monostori, 2008) and a nearly monotypic calcareous nannoplankton flora (see Veselov and Lul'eva, 1980; Krhovský et al., 1992; Nagymarosy and Voronina, 1992; Melinte-Dobrinescu and Bruster, 2008) provide good evidence that salinity in the Paratethys was lower than in the present-day Black Sea. This is in agreement with the suggestion presented by Rusu (1977, 1988) who estimated a salinity between 12 and $15 \%$.

On the other hand, the bivalve assemblages populating the Paratethys during Late Solenovian-Middle Kiscellian are characterized by co-occurrence of dominant endemic Paratethyan elements, with accompanying euryhaline species of boreal origin such as Nucula compta Goldfuss (Nuculidae), Saccella westendorpi (Nyst) (Nuculanidae), Glossus subtransversus d'Orbigny (Glossidae), Peronidia nysti (Deshayes) (Tellinidae), Callista beyrichi (Semper) and Cordiopsis westendorpi (Nyst) (Veneridae), and Cyrtodaria angusta (Nyst et Westendorp) (Hiatellidae). These (mixed) assemblages are known from upper Solenovian shallow-water deposits in Bulgaria (upper Ezerovo Fm., High Thracian Basin; Kojumdgieva and Sapundgieva, 1981), Romania (Lower Dysodilic Fm., Romanian Outer Carpathians; Rusu, 1999), North Ossetia-Alania in the Russian Federation (Tsraudon Suite; Voronina and Popov, 1984), Georgia (Corbula Beds of Guria; Voronina and Popov, 1984; Popov et al., 1993b) and in Kazakhstan (Manaysor Beds of Tamdy Suite of the Northern Ustyurt Plateau; Merklin, 1974; Voronina and Popov, 1984; Popov et al., 1993b). Isochronous, more deep-water sediments, dark clays with pyrite and jarosite, were deposited in anoxic environments (Popov and Stolyarov, 1996). Therefore, we conclude that during the Late Solenovian-Middle Kiscellian the conditions in the Paratethys were similar to those in the present-day Black Sea, i.e. mesohaline with marked stratification of the water column and restricted connections with open seas.

\section{OTHER EARLY OLIGOCENE CARPATHIAN BIVALVE FAUNAS}

\section{NORMAL MARINE FAUNAS}

Occurrences of Early Oligocene bivalve faunas in the Polish Outer Carpathians are extremely rare (Figs. 1 and 9). The only fossiliferous Lower Oligocene deposits are known from the Silesian Nappe, NW of Krosno (Jucha and Krach, 1962). How- 
ever, the molluscan faunas of exploited localities at Gogołów and Kobyle have been treated only in preliminary and incomplete inventories and until now have not been critically worked up, and the taxonomy and nomenclature are still confused and outdated. A total of eleven bivalve species and three gastropod species were recognized within the material sampled from the uppermost Siedliska Conglomerate (or Siedliska Member) of the Menilite Beds (Menilite Formation of Kotlarczyk and Leśniak, 1990) at the Gogołów section. They are (after original attributions given by Krach): Nucula mixta Deshayes, Leda sp., Limopsis cf. nana (Lamarck), Axinea pulvinata (Lamarck), Axinea sp., Phacoides praecinctus Koenen, Miltha elegans (Defrance), Cardium sp., Tellina donacilis Lamarck, Corbula leonina Oppenheim and Cor. angulata (Lamarck), and Turritella sulcifera (Deshayes) var. paucicarinata (Lamark), Turritella sp., and Fusus sp. In the same stratigraphic position (directly above the Globigerina marls representing the uppermost part of the Eocene); at the Kobyle III section only very poor preserved specimens of Leda sp., Phacoides sp. and Pleurotoma sp. were found (Jucha and Krach, 1962).

On the other hand, unique and more diverse molluscan assemblages were documented in Lower Oligocene deposits in the Boryslav-Pokuttya Nappe, Ukrainian Outer Carpathians. These assemblages were recorded in the Subchert Member, coeval with the Siedliska Conglomerate, which crops out immediately below the Chert Member, a significant horizon at the base of the Menilite series (Menilite Formation of Gozhyk et al., 2015) of the Outer Carpathians. The molluscan content of the basal part of the Oligocene Menilite series is known from the studies of Maximov (1961, 1963, 1987), Studencka et al. (1999) and Popov et al. (2009a). The bivalve fauna from the Upper Eocene and the Oligocene Menilite series of the Ukrainian Outer Carpathians has been studied by A. Maximov during the 1950s. His unpublished Ph.D thesis (Maximov, 1959) documenting 63 bivalve species is stored in the Russian State Library in Moscow. Unfortunately, the poor quality of illustrations and lack of access to the original material (apparently lost) preclude any verification of Maximov's determinations. Only descriptions of eight new species were published (Maximov,

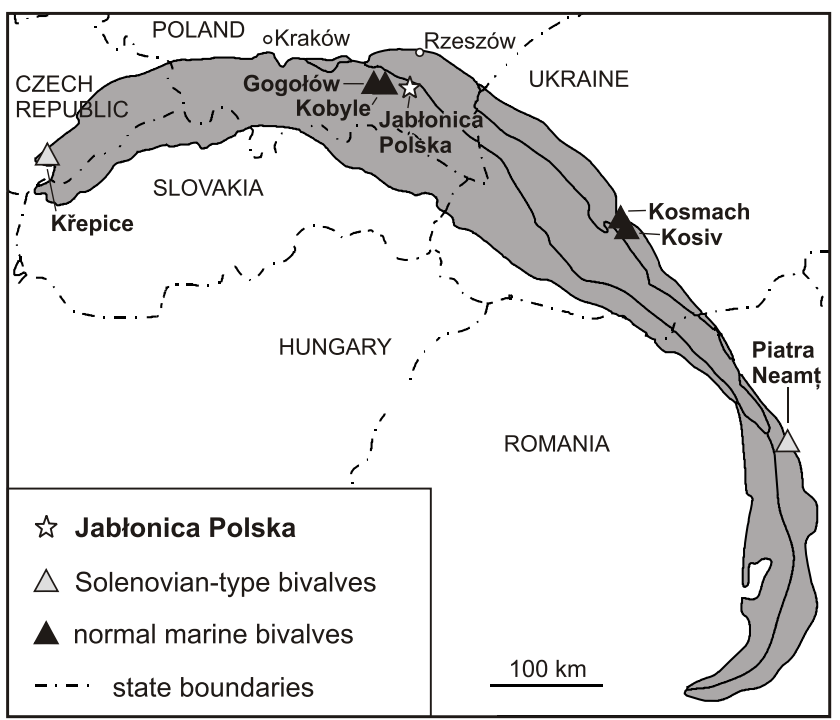

Fig. 9. Schematic map of the Outer Carpathians showing location of the Lower Oligocene molluscan-bearing localities referred to in this paper
1961) and no more than a list of molluscan species is available (Maximov, 1987). The same list of molluscan species was provided by Vyalov et al. (1996).

More recently, taxonomic studies were performed by Studencka et al. (1999) and Popov et al. (2009a). Twice (in 1989 and 2000) the senior authors had the opportunity to undertake fieldwork (in cooperation with O.V. Amitrov, PIN RAS, Moscow) in the Ukrainian Carpathians. Molluscan material was obtained from the basal part (cropping out directly below the Chert Member) of the Menilite Fm. in the Boryslav-Pokuttya Nappe, exposed in the Pistynka River at Kosmach and in the Rybnytsia River at Kosiv (Figs. 9 and 10). These two sections of the Menilite Fm. were the subject of detailed research carried out by Gruzman (1990). Each section comprises a >250 m thick succession of Lower Oligocene-Lower Miocene deposits. The base of its lower part, distinguished as the Lower Menilite Subformation, about $65 \mathrm{~m}$ thick, is marked by the Subchert Member attaining a thickness of $10 \mathrm{~m}$. This unit, represented by a succession of mostly dark grey to black clayey-siliceous shales intercalated with thin sandstones and dark grey calcareous sandstones, contains fish remains (Gruzman et al., 1962). Occasionally, within the upper part of the Subchert Member, bivalve and gastropod shells have been found. By means of an integrated study of planktonic foraminifera and calcareous nannofossils (the NP22 Helicopontosphaera reticulata Zone), an earliest Oligocene age is indicated for the Subchert Member (Andreyeva-Grigorovich, 1987; Gruzman, 1990; Andreyeva-Grigorovich and Gruzman, 1994; Vyalov et al., 1996). The Subchert Member is followed by the Chert Member (Fig. 10B, D), $15 \mathrm{~m}$ thick, composed predominantly of thin- to medium-bedded black cherts and chalcedonites intercalated - in its basal part - with dark shales. Towards the top of the Chert Member, the amount of shales increases and the unit slowly grades into a succession of thin-bedded light grey marls intercalated with dark grey shales. In the basal part of this unit, attaining a thickness of $30 \mathrm{~m}$, a few thin laminated limestone intercalations have been observed. In the opinion of Gruzman (1990) these limestones may be correlated with those described in the Polish Outer Carpathian as the Tylawa Limestones, attributed to the NP23 Zone (see Haczewski, 1989; Ciurej and Haczewski, 2012). The Lower Menilite Subformation terminates with a $10 \mathrm{~m}$ thick sequence of sandstones of Kliwa-type which contains foraminifera suggesting an Early Oligocene age (Gruzman, 1990).

The layers of the Subchert Member, containing molluscan material, reveal sedimentary structures indicating that they were deposited by debris flows (Fig. 10C). Thirty two bivalve species and 11 gastropod species have been identified within the material taken from the Pistynka River section at Kosmach and 15 bivalve species and 5 gastropod species have been recognized in the Rybnytsia River section at Kosiv (Popov et al., 2009a). The taxonomic composition of the bivalve fauna from both Kosmach and Kosiv sites is summarized in Table 2. Selected species are shown in Figures 11 and 12. Ecologically, the fauna consists of two marine biotic communities. One is represented by typical shoreline dwellers strongly dominated by thick-shelled representatives of the genus Glycymeris da Costa which favoured sandy environments in the littoral down to depths of a few metres. On the other hand, small $(<1 \mathrm{~cm})$ and delicate thin-shelled burrowing Thyasira, e.g., Th. benedeni (De Koninck), Th. inopinata Maximov and Th. turgida Maximov found at Kosmach locality; Th. benedeni (De Koninck) and Th. obtusa (Beyrich) from Kosiv, is considered to be important component of the circumlittoral community inhabiting organically enriched sandy muds or clays at 50-100 m depth. Some species 

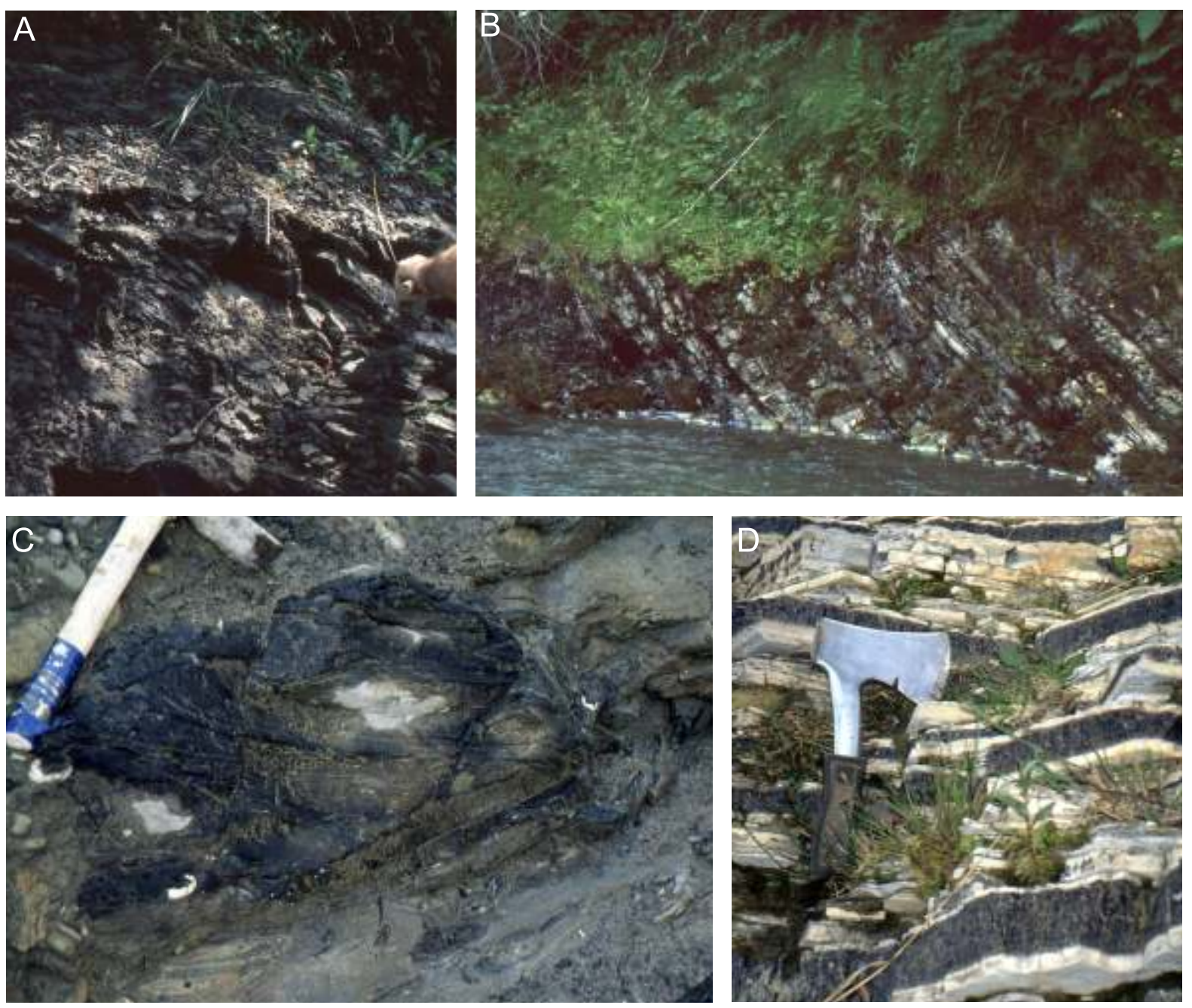

Fig. 10. Exposures of the Menilite Formation in the the Boryslav-Pokuttya Nappe, Ukrainian Carpathians

A - dark grey and black clayey-siliceous shales of the Subchert Member containing molluscan shells and fish remains, $\mathbf{B}-$ the higher part of the Subchert Member (left) covered by a succession of thin-bedded cherts, $\mathbf{C}$ - detail of the Subchert Member: the shales display chaotic structures indicating that these strata represent slump deposits, $\mathbf{D}$ - medium and thin-bedded black cherts of the basal part of the Chert Member; A, B - Kosiv upon Rybnytsia; C, D - Kosmach upon Pistynka

of the genus Thyasira Lamarck have established symbiotic relationships with chemoautotrophic bacteria in their gills, the metabolism of which contributes considerably to the nutrition of the bivalve while other species are asymbiotic (Taylor et al., 2007).

Within the bivalve assemblages in question, genera of northern origin prevail, the boreal influences thus being clear. In addition, according to data by Dreger (1904) and Löffler (1999), the Ukrainian bivalve assemblages show a resemblance to the Lower Oligocene fauna from Tirol. In respect to the biogeographic affinities, the occurrence of Limopsis goldfussi (Nyst), Oblimopa ?costulata (Goldfuss), Glycymeris aff. tenuisulcata (Koenen), Gonimyrtea droueti (Nyst), "Lucina" [?Pseudomiltha] rostralis (Mayer et Gümbel), Thyasira benedeni (De Koninck), Th. obtusa (Beyrich), Cyclocardia depressa (Koenen), Astarte cf. gracilis Münster in Golfuss, A. cf. falsopropinqua R. Janssen, Habecardium cf. tenuisulcatum (Nyst) and Callista splendida (Mérian in Goldfuss) places the Carpathian fauna within the North European Region proposed by Popov et al. (2002) [or the Proto-Atlantic-Boreal Region of Harzhauser et al. (2002)] with strong links with those of the German Province, whilst typical elements from the Proto-Mediterranean are missing or very rare. Of
12 bivalve species from Kosmach noted by Maximov (1987) only Cardita laurae Brongniart is a typical Mediterranean species. However, on the basis of description and illustration given by Maximov (1987: 72, pl. 1, figs. 3, 4) the specimens assigned to Cardita laurae show a close resemblance to Acturellina oswaldii (Slodkevich) recorded in the Upper Eocene of the southern Ukraine and the Lower Oligocene of Crimea (Popov et al., 1993). According to Maximov (1987), the Carpathian molluscan fauna displays high similarities with those from the Lower Oligocene (Khadumian) of Crimea and Ciscaucasia. The present authors agree with Studencka et al. (1999) and Popov et al. (2009a) that the occurrence in the Carpathian material investigated of the bivalve genus Barbatia Gray, diverse lucinids and representatives of gastropod families Turritellidae Lovén, Volutidae Rafinesque, Conidae Fleming and Marginellidae Fleming justifies the difference between the molluscan fauna from the Carpathian Early Oligocene strata and the Khadumian assemblages from both Crimea and Ciscaucasia. In addition, no Paratethyan endemics known from the Khadumian Province have been found among the Carpathian fauna (Popov et al., 2009b). 
Table 2

List of Early Oligocene bivalves derived from the Subchert Member of the Menilite Formation in the Ukrainian Carpathians that are housed in the Polish Academy of Sciences Museum of the Earth in Warsaw, Poland

\begin{tabular}{|c|c|c|c|}
\hline Family & Species & KoP & KoR \\
\hline $\begin{array}{l}\text { Nuculanidae H. Adams et A. Adams, } \\
1858\end{array}$ & Saccella sp. & $x$ & \\
\hline Arcidae Lamarck, 1809 & $\begin{array}{l}\text { Barbatia sp. } \\
\text { Bathyarcasp. }\end{array}$ & $\mathrm{x}$ & $x$ \\
\hline Limopsidae Dall, 1895 & $\begin{array}{l}\text { Limopsis goldfussi (Nyst, 1843) } \\
\text { Limopsis sp. } \\
\text { Oblimopa? costulata (Goldfuss, 1837) } \\
\text { Pectunculina sp. }\end{array}$ & $\begin{array}{l}X \\
X \\
X \\
X\end{array}$ & $x$ \\
\hline Glycymerididae Dall,1908 (1847) & $\begin{array}{l}\text { Glycymeris aff. tenuisulcata (Koenen, 1893) } \\
\text { Glycymeris sp. [?obovata Lamarck, 1819] }\end{array}$ & $\begin{array}{l}X \\
X\end{array}$ & $\begin{array}{l}X \\
X\end{array}$ \\
\hline Pectinidae Wilkes, 1810 & $\begin{array}{l}\text { gen. sp. indet. } \\
\text { ?Chlamys sp. }\end{array}$ & $\mathrm{x}$ & $\mathrm{X}$ \\
\hline Lucinidae Feming, 1828 & $\begin{array}{l}\text { Lucina cf. orbicularis Linnaeus, } 1758 \\
\text { "Lucina"[? Gonimyrtea] cf. gracilis Nyst, } 1843 \\
\text { Gonimyrtea droueti (Nyst, 1861) } \\
\text { “Lucina”[?P Pseudomiltha] rostralis (Mayer et } \\
\text { Gümbel, 1861) } \\
\text { ?Myrtea sp. }\end{array}$ & $\begin{array}{l}x \\
X \\
x \\
x\end{array}$ & $\mathrm{X}$ \\
\hline Thyasiridae Dall, 1900 (1895) & $\begin{array}{l}\text { Thyasira benedeni (De Koninck, 1838) } \\
\text { Thyasira inopinata Maximov, 1987 } \\
\text { Thyasira obtusa(Beyrich, 1848) } \\
\text { Thyasira turgida Maximov, 1987 } \\
\text { Thyasira sp. } 1\end{array}$ & $\begin{array}{l}X \\
X \\
X \\
X\end{array}$ & $\begin{array}{l}x \\
x\end{array}$ \\
\hline Carditidae Férussac, 1822 & $\begin{array}{l}\text { Cardites sp. } 1 \\
\text { Cardites sp. } 2 \\
\text { Cyclocardia depressa (Koenen, 1884) } \\
\text { Cyclocardia?orbicularis(Sowerby, 1825) } \\
\text { Cossmanella sp. }\end{array}$ & $\begin{array}{l}X \\
x \\
X \\
X \\
X\end{array}$ & $\mathrm{x}$ \\
\hline Astartidae d'Orbigny, 1844 & $\begin{array}{l}\text { Astarte cf. gracilis Münster in Golfuss, } 1837 \\
\text { Astarte cf. falsopropinqua R. Janssen, } 1979 \\
\text { Astarte ex gr. plicata Mérian in Sandberger, } \\
1863 \\
\text { Astarte sp. }\end{array}$ & $\begin{array}{l}X \\
x \\
x\end{array}$ & $x$ \\
\hline Crassatellidae Férussac, 1822 & ?Crassinella sp. & $\mathrm{X}$ & \\
\hline Cardiidae Lamarck, 1809 & $\begin{array}{l}\text { Habecardium cf. tenuisulcatum (Nyst, 1836) } \\
\text { Habecardium cf. excomatulum (Glibert et Van } \\
\text { de Poel, 1970) }\end{array}$ & $\mathrm{X}$ & $x$ \\
\hline Veneridae Rafinesque, 1815 & $\begin{array}{l}\text { Callista splendida(Mérian in Goldfuss, 1860) } \\
\text { Callista cf. sublaevigata (Nyst, 1845) } \\
\text { Callista sp. } \\
\text { Pitar?bosqueti(Hebert, 1849) }\end{array}$ & $\begin{array}{l}X \\
X \\
X \\
X\end{array}$ & $\begin{array}{l}x \\
x\end{array}$ \\
\hline Corbulidae Lamarck, 1818 & $\begin{array}{l}\text { Corbula gibba (Olivi, 1792) } \\
\text { Caryocorbula cf.cuspidata(Sowerby, 1822) }\end{array}$ & $\mathrm{x}$ & $\mathrm{x}$ \\
\hline
\end{tabular}

KoP - Kosmach upon Pistynka; KoR - Kosiv upon Rybnytsia

\section{SOLENOVIAN - TYPE BIVALVES}

The Carpathian Early Oligocene fauna discussed in this paper shows great similarities to the coastal faunas described from the Solenovian deposits from Ukraine to Kazakhstan, with several co-occurrences at the species level. Similar bivalve assemblages, distinguished at the genus level, have been described from the Dynów Marlstone cropping out at Křepice (Ždanice Unit, Moravian Outer Carpathians), where Korobkoviella cf. lipoldi (Rolle) occurs in association with ?Lentico- 
A1

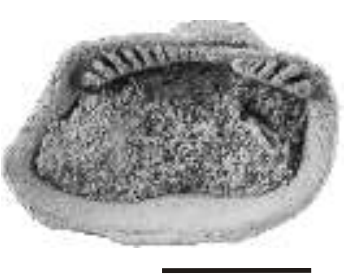

A2

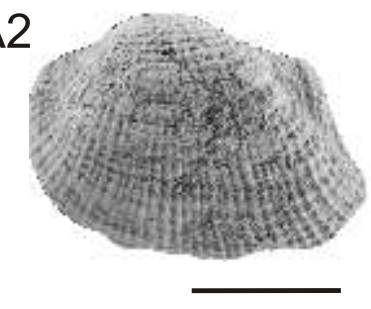

B1

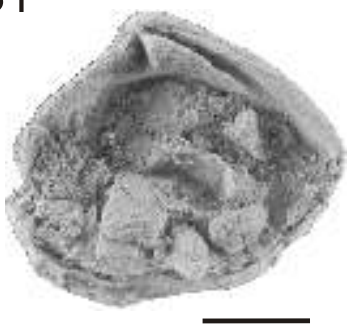

C

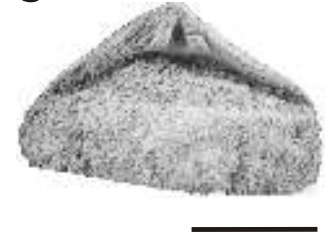

D

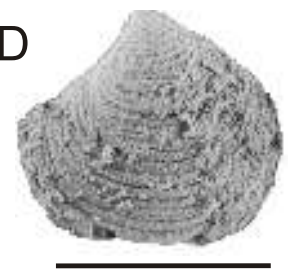

B2
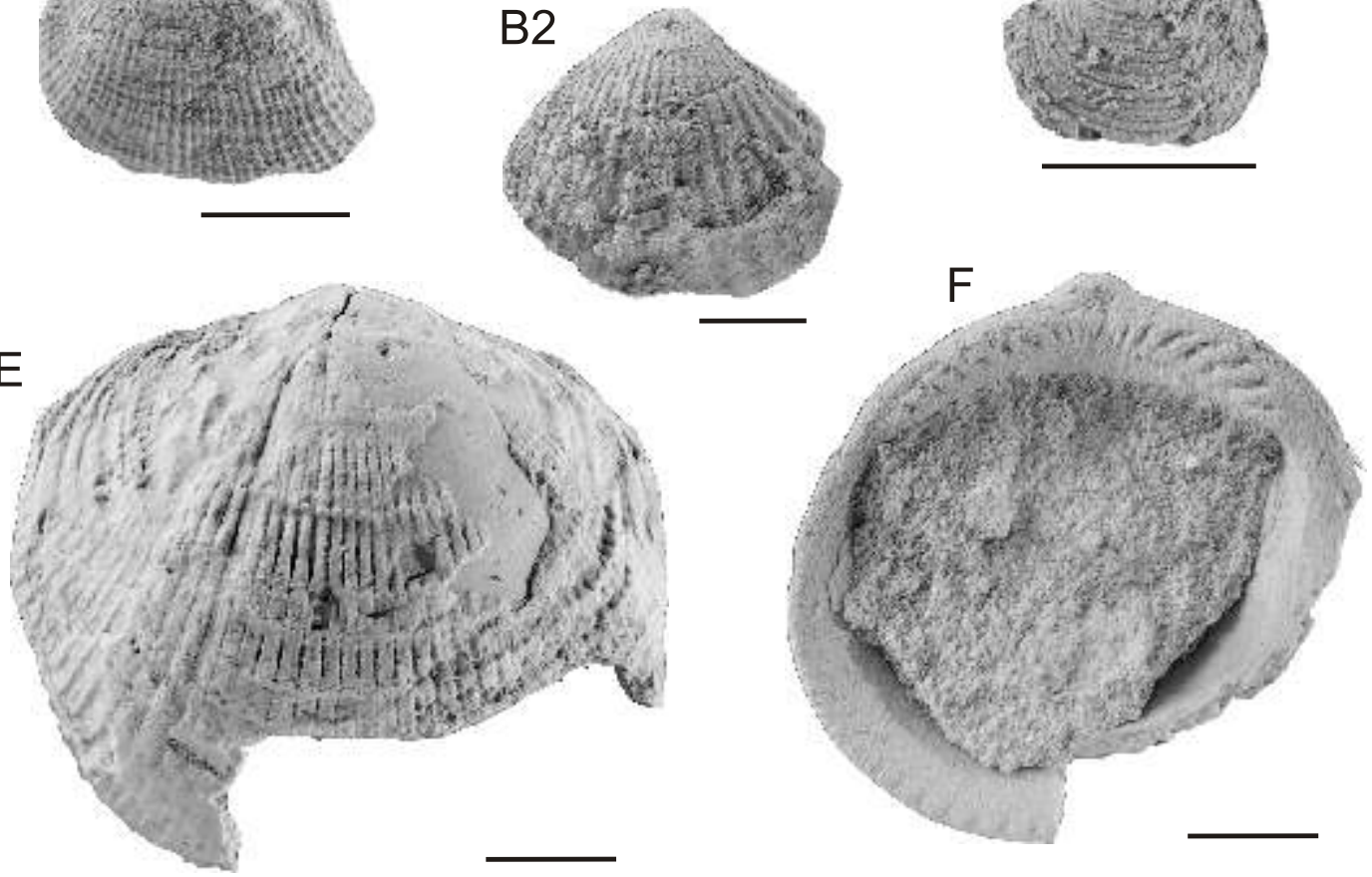

Fig. 11. Selected Early Oligocene shallow-water bivalves from the Boryslav-Pokuttya Nappe, Ukrainian Carpathians

A1, A2 - Barbatia sp. (MZ VIII MI-3905): A1 - interior of left valve, A2 - exterior of left valve; B1, B2 - Cardites sp.1 (MZ VIII MI-3921): B1 - interior of right valve, B2 - exterior of right valve; C - Astarte cf. gracilis Münster in Golfuss, 1837, interior of left valve (MZ VIII MI-3926/1); D - Astarte cf. falsopropinqua R. Janssen, 1979, exterior of left valve (MZ VIII MI-3927); E - Glycymeris aff. tenuisulcata (Koenen, 1893) exterior of left valve (MZ VIII MI-3940/1); F - Glycymeris aff. tenuisulcata (Koenen, 1893), interior of right valve (MZ VIII MI-3910/1); scale bars 5 mm; A-D, F - Kosmach upon Pistynka; E - Kosiv upon Rybnytsia

rbula sp. (Čtyroký, 1991). Moreover, based on the collections stored at the Faculty of Science, University in Brno, the presence of Urbnisia cf. lata (Goncharova) and Korobkoviella cf. kiktenkoi (Merklin) has been documented at Křepice (Popov and Studencka, 2015). Detailed stratigraphic analyses were provided by Krhovský (1981), Krhovský et al. (1992) and Švábenická et al. (2007) who, based on the calcareous nannofossil content, placed the Dynów Marlstone in the NP23 Sphenolithus predistentus Zone of Martini, the estimated age of which is between 29.9 and $32.3 \mathrm{Ma}$.

A corresponding bivalve fauna has also been documented at the Piatra Neam site from both Bituminous Marls and Lower Dysodilic Fm. in the Marginal Folds Nappe, Romanian Outer Carpathians (Rusu, 1999). According to Rusu (1999), the bivalve fauna from the Bituminous Marls includes: Korobkoviella lipoldi (Rolle), Polymesoda convexa (Brongniart), Lenticorbula sokolovi (Karlov) and Janschinella garetzkii (Merklin). Exami- nation of bivalves documented at the Lower Dysodilic Fm. revealed Cerastoderma cf. serogosicum (Nossovsky), Korobkoviella lipoldi (Rolle), Urbnisia lata Goncharova, Polymesoda convexa (Brongniart) and Janschinella garetzkii (Merklin). This unit also sporadically contains the euryhaline boreal origin species Nucula compta Goldfuss, Saccella westendorpi (Nyst) and Glossus subtransversus d'Orbigny. In the opinion of Rusu (1999) this suggests brief episodic connection with the North Sea. However, it must be emphasized that bivalve-bearing sediments were also deposited by gradient currents from near-shore to shelf settings. According to Melinte-Dobrinescu and Brustur (2008), levels of laminated coccolith limestones identified within the Lower Dysodilic Fm. may be correlated with those described in the Polish Outer Carpathian as the Tylawa Limestones (see Haczewski, 1989; Ciurej and Haczewski, 2012) and they yielded bloom assemblages of Reticulofenestra ornata Müller and Transversopontis fibula Ge a usually without 

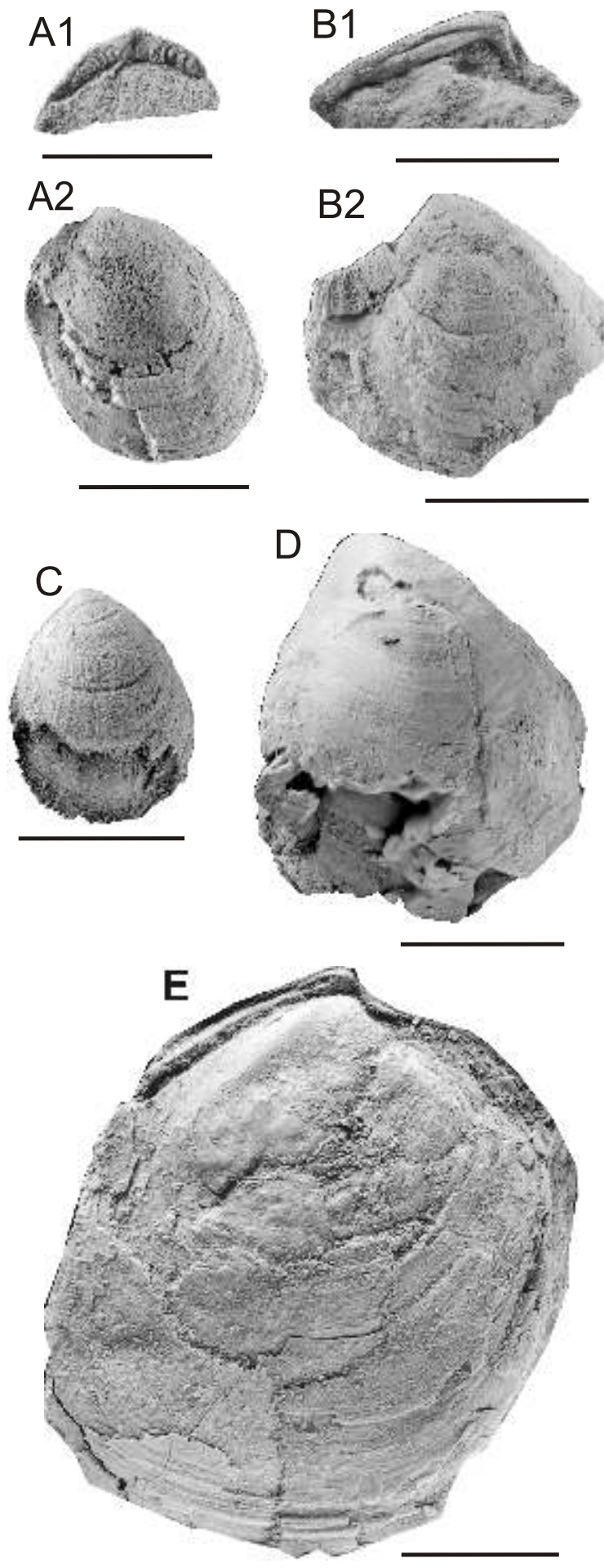

Fig. 12. Selected Early Oligocene relatively deep-water bivalves from the Boryslav-Pokuttya Nappe, Ukrainian Carpathians

A1, A2 - Limopsis goldfussi (Nyst, 1843), (MZ VIII MI-3938/1): A1 interior of left valve, A2- exterior of left valve; B1, B2 - Thyasira inopinata Maximov, 1987 (MZ VIII MI-3918/1) ): B1 - interior of left valve, B2 - exterior of left valve; C - Limopsis goldfussi (Nyst, 1843), interior of left valve (MZ VIII MI-3906/1); D - Thyasira turgida Maximov, 1987, exterior of left valve, (MZ VIII MI-3919/1); E "Lucina" [? Pseudomiltha] rostralis (Mayer et Gümbel, 1861) articulated shell, view of right valve (MZ VIII MI-3943/1); scale bars $10 \mathrm{~mm}$; A, E - Kosiv upon Rybnytsia; B-D - Kosmach upon Pistynka any other species. The low-diversity calcareous nannoflora recorded from the Lower Dysodilic Fm. is indicative of NP23 Zone (Melinte, 2005; Melinte-Dobrinescu and Brustur, 2008).

The above review clearly shows that the fauna from the Jabłonica Polska sites, dominated by Cerastoderma serogosicum (Nossovsky) and Janschinella vinogrodskii (Merklin) appears to be the most diverse Carpathian assemblage. The fauna studied from the Polish Outer Carpathians is also one of the most diverse within coeval deposits of the whole Paratethys: the only more diverse Solenovian bivalve assemblage is found in Akhalcikhe, Georgia (Popov and Titova, 1982; Kazakhashvili, 1984; Popov et al., 1993a). In contrast to bivalve shells from Jabłonica Polska, generally unfavourably preserved, those from Akhalcikhe are very well preserved.

\section{THE BIRTH OF THE PARATETHYS: AN OVERVIEW AND COMMENTS}

The term Paratethys was introduced by Laskarew (1924) to describe an intercontinental sea (extending over a large area from the Rhôn to the current position of the Aral Sea, for a distance of about $4,500 \mathrm{~km}$ ) that formed north of the Alpine mountain belt in the Early Miocene (Burdigalian). According to Laskarew (1924), both environmental settings and fauna inhabiting the Paratethys Sea during the Early and Middle Miocene did not differ from those prevailing during that time in the [Mediterranean] Tethys ${ }^{1}$. Only at the beginning of the Sarmatian (Late Miocene), simultaneously with the isolation of the Paratethys, its fauna lost these similarities and until the end of Neogene was developing independently from that of the Tethys.

Laskarew's (1924) concept of the Paratethys was re-defined several times over the years. Especially, the time when the Paratethys came into existence has been strongly debated. Below we discuss all important aspects and definitions of the date of the Paratethys origin. Major progress in this field was made by Seneš $(1960,1966)$ who made important contributions to the knowledge of the complicated history of the Paratethys Sea. According to Seneš (1960), the Paratethys formed around the Oligocene-Miocene boundary which coincided chiefly with the final separation between the intercontinental Central European seas and the North Sea. Based on its geodynamic and palaeobiological development, he proposed dividing the history of the Central Paratethys into three evolutionary stages: Eoparatethys (Early Miocene, Aquitanian until the end of the Helvetian, now known to be latest Karpatian coeval with the latest Burdigalian), Mesoparatethys (late Early Miocene until early Middle Miocene, Karpatian-Middle Tortonian now known to be Middle Badenian) and Neoparatethys (Middle Miocene till the end of the Neogene). As regards faunas, in the opinion of Seneš (1960), the changes in palaeogeography were reflected by the immigration of both Western Mediterranean and Atlantic taxa along with occasional occurrences of typical northern elements.

${ }^{1}$ In the Laskarew's paper the sentence on p. 5 reads: Ainsi, pendant les époques du miocéne inférieur (burdigalien - I étage méditerranéen) et moyen (vindobonien - II étage méditer.) sur toute l'étendue de la Paratéthys régnaient des conditions et des faunes semblables et parfaitement uniformes à celles de la Téthys. L'isolation de la Paratéthys à l'époque du miocène supérieur (sahélien ? - sarmatien) provoqua une divergeance des conditions et des faunes de la Téthys et Paratéthys qui s'accrû continuellement jusqu' à la fin des périodes néogènes. 
Seneš (1966) subsequently introduced the Transeuropean bioprovince as a biogeographic entity to which the Paratethys has been held to be correlative and virtually synonymous. As the complexities of the Paratethys became clearer Seneš (1971) proposed a regional division into Western, Central and Eastern Paratethys, each recording a different environmental history. Therefore, new regional stages have been introduced and stabilized in the three individual areas. As the oldest stage within the Central (and Western) Paratethys the Egerian has been indicated, roughly correlating to the Middle Chattian-Early Aquitanian. As a consequence, the duration of the Paratethys Sea, limited earlier to the Neogene (Laskarew, 1924; Seneš, 1960), has been extended to the Late Oligocene. Rusu (1977) modified the concept of the Transeuropean bioprovince as typified by Seneš (1966), limiting this term to the Early Oligocene (Rupelian) time while the term Paratethys continued to be used only for the period beginning since Egerian time (mid Late Oligocene). Of significant impact to this statement were findings of peculiar bivalve faunas in the Lower Oligocene deposits of the Transylvanian Basin. This molluscan fauna includes (after original attributions given by Rusu, 1977), among others, Lentidium aff. ustjurtense Merklin, Cardium lipoldii Rolle, C. serogosicum Nossovsky, Congeria aralensis Merklin, Lentidium vinogrodskii Merklin, Corbula sokolovi sokolovi (Karlov), Cor. sokolovi zhizchenkoi Merklin and Rzehakia cimlanica Popov. The occurrence of these bivalves along with the endemic calcareous nannoplankton species Reticulofenestra ornata Müller, according to Rusu (1977), had considerable importance for the correlation of the Transylvanian Oligocene to the Euxine-Caspian Lower Oligocene (Solenovian). Extensive geological and palaeontological investigations undertaken by Báldi $(1979,1980)$ in the Hungarian Paleogene Basin were strongly consistent with the data from the Transylvanian Basin acquired by Rusu (1977). Contrary to previously held assumptions concerning the date of the Paratethys origin Báldi $(1979,1980)$ postulated that this happened in the earliest Oligocene, and introduced the Kiscellian as the first regional Central Paratethyan stage, above the Priabonian and below the Egerian. According to Báldi (1979, 1980), the Paratethys origin was reflected by abrupt, fundamental change in the depositional system: the carbonate succession was interrupted by siliciclastic sedimentation. Báldi $(1979,1980)$ associated this important shift in lithology from carbonate to terrigenous deposition with the major change in benthic faunas: clear Western Tethyan affinities were replaced by strong boreal influences.

There are, however, several problems associated with the criteria defining the date of the Paratethys birth as given by Báldi (1979, 1980). Firstly, it is now clear that the palaeogeographic separation of the Northern Peri-Tethys basins from the World Ocean was during Late Paleogene time (Nevesskaja et al., 1987; Rögl, 1998, 1999; Meulenkamp et al., 2000; Popov et al., 1993a, 2002, 2004; Meulenkamp and Sissingh, 2003). Secondly, in spite of the broad connection of particular basins within the Northern Peri-Tethys (Fig. 13), a homogeneous fauna and flora had not developed, due to conspicuous climatic latitudinal zonations that occurred during this interval (Popov, 1994; Amitrov, 1996, 1998). The Eocene-Oligocene boundary witnessed a significant reorganization of biota inhabiting the Euxine-Caspian area of the Northern Peri-Tethys; the Eastern Paratethys is considered as its palaeogeographical and geological descendant. Drastically reduced diversity of both plankton and benthos has been observed even along its southern marginal parts. Significant faunal impoverishment coinciding with strong endemism led to the origin of the Khadumian Province within the North European Region, as proposed by Popov et al. (2002). Generally, at generic level the earliest Oligocene molluscan fauna of the Khadumian Province displays affinities to those of the Rupelian in Belgium, France and Germany (Popov et al., 1993b, 2002; Amitrov, 1996, 1998). As observed for the bivalves, the eastern part of the Euxine-Caspian Basin System seems to have acted as the centre of origin. The earliest certain record of Cerastoderma mutabile Popov, Janschinella garetzkii (Merklin), J. vinogrodskii (Merklin) Lentidium ianischewskii (Ruchin), L. ustjurtense Merklin and Corbula sokolovi (Karlov) is from the basal Oligocene deposits assigned to nannofossil zone NP22 (Voronina and Popov, 1984; Popov et al., 2002). Some of these species viz., Lentidium ianischewskii and L. ustjurtense occur locally abundantly in the Northern Ustyurt Plateau, Kazakhstan (Merklin, 1961, 1974) and were probably estuary-dwellers (Voronina and Popov, 1984; Popov et al., 2002).

In contrast, at the same time (earliest Oligocene: NP21-NP22 zones) the central part of the Northern Peri-Tethys formed a complex system of basins with various sedimentary patterns and ecosystems influenced by changing seaways between the North Sea and the Proto-Mediterranean Sea (Popov et al., 1993a, 2002, 2004; Rögl, 1998, 1999; Meulenkamp et al., 2000; Fig. 9). As reflected by molluscan fauna from the Mera Fm. (NP22 Zone), the Transylvanian Basin remained connected to the North Italian Basin (Moisescu, 1972; Rusu, 1977, 1988). Despite the change in depositional system (latest Eocene coral reefs are in strong contrast with the Early Oligocene coastal siliciclastic succession) the Thracian Basin was still part of the Western Tethys (Íslamoğlu et al., 2010). On the other hand the Hungarian Paleogene Basin communicated with the North Sea via the North Alpine Molasse Basin (which opened at this time into the Rhine Graben), as marked by planktonic foraminifera and the pelagic thecosomatous pteropod genus Limacina Bosc from the lower Tard Clays (Báldi, 1980, 1984, 1986). The molluscan fauna from the basal part of the Menilite Formation in the Ukrainian Outer Carpathians - as documented by Studencka et al. (1999) and Popov et al. (2009a) - displays a northern affiliation. In fact, a great difference in species composition between faunas of particular basins is observed. Up to the earliest Oligocene (assigned to NP22 Zone), the molluscan fauna populating the Transylvanian and Thracian basins as well as these living in the area of a present-day Armenia show a clearly Western Tethyan affiliation (Moisescu, 1972; Rusu, 1977; Voronina and Popov, 1984; Íslamoğlu et al., 2010). On the other hand, a boreal character is obvious for the earliest Oligocene assemblages inhabiting the North Alpine, Hungarian Paleogene and Carpathian Flysch basins (Báldi, 1986; Löffler, 1999; Studencka et al., 1999; Popov et al., 2002, 2009a, 2009b; our study).

Báldi (1984) was of the opinion that mass occurrence of Limacina species might indicate the lower boundary of the Kiscellian and provide a very good correlation criterion with the Euxine-Caspian area of the Northern Peri-Tethys. In fact, at least two horizons with small pteropod shells, known as the Spiratella level [Spiratella Blainville is an objective synonym of Limacina; Spirialis Eydoux et Souleyet is regarded to be its younger synonym] were recognized in the same stratigraphic position i.e. just below the deposits yielding bivalve shells of Korobkoviella and Janschinella species, in both the Hungarian Paleogene (Báldi, 1984, 1986) and Molasse basins (Seifert et al., 1991). Indeed, Limacina shells become quite abundant also in the basal part of the Menilitic Fm. in the Carpathian Flysch basins (Krhovský et al., 1992; Bubik et al., 2005) and in the Lower Maykopian strata in Georgia, the Northern Peri-Tethys (Popov et al., 2009b). However, Báldi's idea does not gain credence because Krhovský et al. (1992), Rusu (1995), Rusu et al. (1996), Bohn-Havas et al. (2004), Kotlarczyk et al. (2006), Popov et al. (2009b), and 
Kotlarczyk and Uchman (2012) noticed the different ages of the Limacina [= Spiratella] horizons. The latter, located in the lowermost Tard Clay in the Hungarian Paleogene Basin, are linked to the boundary between the NP21and NP22 zones in the magnetic chron C13n, around 33.2 Ma ago (Bohn-Havas et al., 2004) while those from the Subchert Member of the Menilitic Fm. in the Ždánice Unit, Moravian Outer Carpathians are attributed to the terminal part of the NP22 Zone by Krhovský et al. (1992). Additionally, these authors (Krhovský et al., 1992) assert the occurrence of layers with Limacina cf. umbilicata (Bornemann) as the result of mass mortality and noted that factors controlling mortality of these organisms were either short-term decreases in surface water salinity or a rise of the $\mathrm{H}_{2} \mathrm{~S}$ poisoned water level. There are also some differences between the Georgian [Transcaucasian] and Hungarian Oligocene pteropod findings such as the considerably earlier appearance (in the NP21 Zone) of Limacina species [referring to the Planorbella Beds] in Georgia (Popov et al., 2002, 2009b). In the Polish Outer Carpathians (Skole Nappe) Limacina species were recovered from the Siedliska Member (top of the NP21 Zone; Kotlarczyk et al., 2006; Kotlarczyk and Uchman, 2012). On the other hand, in the Transylvanian Basin the genus Limacina occurs exclusively in well-known bituminous shales of the Bizusa Fm. belonging to the Janschinella garetzkii total-range zone (Rusu, 1995; Rusu et al., 1996) which is attributed to the NP23 Zone (Melinte-Dobrinescu and Brustur, 2008).

In the course of the Early Oligocene, particularly around the boundary between the NP22 and NP23 zones, a fundamentally new palaeobiogeographic and palaeogeographic setting arose to the north of a continental barrier formed by a chain of mountains and microcontinents e.g., Alps, Dinarids, Balkanides, Hellenides, Pontids, Anatolian Massif, Lesser Caucasus, Elburz and Kopeth Dagh. In response to the closure of seaways towards the Proto-Mediterranean Sea (Transylvanian and Thracian basins) and restricted connection with the North Sea (Fig. 14), molluscan diversity decreased and an endemic bivalve fauna evolved, spreading towards the west as far as the North-Alpine Molasse Basin (Seifert et al., 1991). Tectonic activity, geodynamics, oceanographic and climatic changes which led to this crucial reorganization of the Northern Peri-Tethys have been discussed in detail elsewhere (e.g., Rusu, 1977, 1988; Báldi, 1979, 1980, 1984, 1986, 1989; Rögl, 1998, 1999 ; Steininger and Wessely, 2000; Meulenkamp et al., 2000; Popov et al., 1993a, 2002, 2004, 2009b; Schulz et al., 2004). Contemporaneously with this environmental changes, great taxonomic similarities are observed between the bivalve assemblages, documented in the upper Tard Clays in the Hungarian Paleogene Basin (Báldi, 1980, 1986), the Bizuşa and lleanda formations in the Transylvanian Basin (Rusu, 1977, 1988; Rusu et al., 1996), the Middle and Upper Ezerovo Fm. in the High Thrace Basin (Kojumdgieva and Sapundgieva, 1981), the Pýnarhisar Fm. in the Thrace Basin (Íslamoğlu et al., 2010), the Schöneck Fm. in the Molasse Basin (Seifert et al., 1991) as well as in the Dynów Marls (Čtyroký, 1991; our study) and the Lower Dysodilic Fm. in the Outer Carpathians (Rusu, 1999). Corresponding faunas are well-known from the Solenovian deposits from Ukraine and as far east as Kazakhstan in the Euxino-Caspian area (Voronina and Popov, 1984, 1985; Popov et al., 1985, 1993b, 2002). The appearance of bivalves belonging to highly endemic genera such as Korobkoviella Merklin, Janschinella Merklin, Lenticorbula Merklin and Ergenica G. Popov, Urbnisia Goncharova in both the Transylvanian and Thracian basins coincides with the incoming of the formerly boreal species Nucula compta Goldfuss, Saccella westendorpi (Nyst), Parvicardium scobinula (Merian in Deshayes) and Peronidia nysti (Deshayes) (Rusu, 1977, 1988; Kojumdgieva and Sapundgieva, 1981; Íslamoğlu et al., 2010). These latter species are already encountered in the lowermost Oligocene strata (NP22 Zone) of the Exine-Caspian area of the Northern Peri-Tethys (Popov et al., 1993b). This faunal turnover marks the stratigraphic interval in better way than the diachronous occurrences of Limacina species, and it is clearly not dependant on facies changes.

Briefly summarizing, the normal marine conditions prevailing in the Northern Peri-Tethys during the NP21 and NP22 zones (32.3-33.9 Ma) were replaced in the NP23 Zone (29.9-32.3 Ma) by pliohaline conditions (12-15\%) with a vertical density water-column stratification. This event caused a distinct faunal turnover from the diverse boreal or Tethyan bivalve faunas populating the Northern Peri-Tethys in the earliest Oligocene to the highly endemic dominant genera. That particular event indicated by the sudden evolution and dispersal of an endemic fauna is eminently suitable to mark the birth of the Paratethys as first discussed by Rusu $(1977,1988)$ and subsequently by Báldi (1989) and Meulenkamp et al. (2000). Rusu (1988) also concluded that the lower boundary of the Kiscellian, the initial Central Paratethyan regional stage, should be placed at the same time as the Paratethys arose.

Consequently, by proposing to place the Lower Kiscellian boundary at the base of the NP23 Zone, Rusu (1988) dated the lowermost Oligocene strata of both Transylvanian and Hungarian Paleogene basins as Merian in age. The time span of the latter Central Paratethyan stage proposed by Marinescu (1975) and re-defined by Rusu (1988) is roughly contemporaneous to the Pshekhian Eastern Paratethyan regional stage (Fig. 5). Up to today, however, the timing of the Kiscellian remains vague: there is no real consensus about the age of its lower boundary. In many publications the Lower Kiscellian boundary is equated with Eocene/Oligocene boundary at $33.9 \mathrm{Ma}$. The use of the base of the NP23 Zone to define the base of Kiscellian (Rusu, $1988,1995)$ places the age of the Kiscellian boundary at 33.2 Ma. On the other hand Piller et al. (2007: fig. 1), describing the current status of particular Central Paratethyan stages, connected the Lower Kiscellian boundary with the Ru2 lowstand of Hardenbol et al. (1998) which approximates the boundary of the CP17 and CP18 zones in the Okada and Bukry zonal scheme (ranges within Zone NP23). This means that the well-established utility of this stage for correlation will only grow with further work.

The bivalve fauna inhabiting the newly formed Paratethys is characterized by a decreased number of families, impoverished generic composition and the absence of marine stenohaline taxa. It was dominated by endemic taxa belonging to euryhaline bivalve families, of which the family Cardiidae reaches particularly high taxonomic diversity. Simply stated, after a dramatic change of environmental factors, strong endemism within the bivalve fauna occurred throughout the Paratethys, which coincides with a specific ostracod association (e.g., Nikolaeva, 1998; Popov et al., 2002; Monostori, 2008) and monospecific nannoplankton (Reticulifenestra ornata Müller, Transversopontis fibula $\mathrm{Ge}$ a and/or T. latus Müller) blooms (Veselov and Lul'eva, 1980; Voronina and Popov, 1985; Nagymarosy and Voronina, 1992; Rögl, 1998, 1999; Popov et al., 1993a, 2002; Melinte-Dobrinescu and Bruster, 2008). In general, during that time brackish water conditions with pliohaline salinity (12-15\%) are proposed for the Paratethys (e.g., Rusu, 1977, 1988; Popov et al., 1985, 1993a, 2004; Popov and Stolyarov, 1996; Schulz et al., 2004). A stratified water column may have caused temporarily anoxic conditions on the sea bottom, during which only very limited benthic life was possible (see Kotlarczyk and Uchman, 2012). By this event (during the NP23 Zone) the Paratethys was united in a single, very distinct biogeographic 


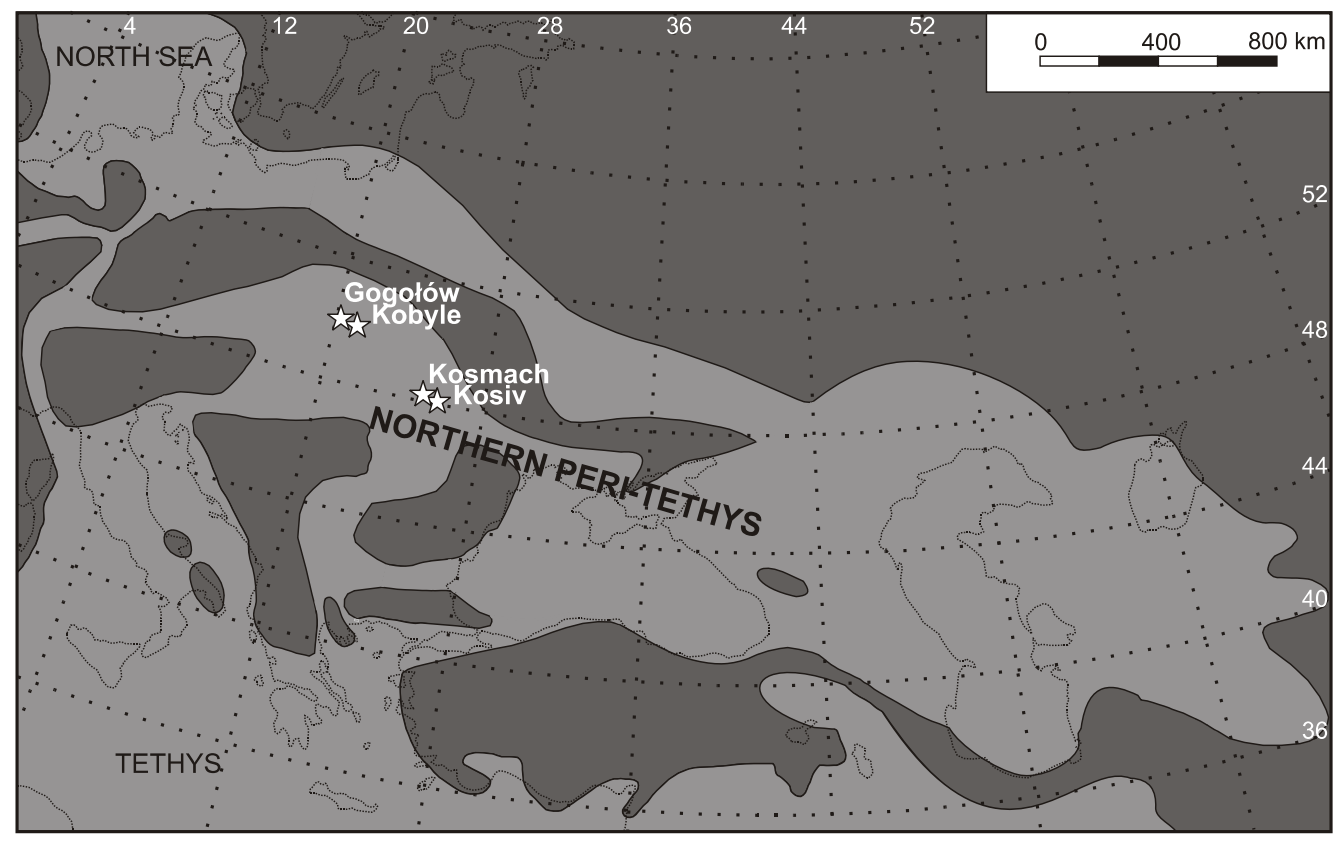

Fig. 13. Palaeogeographical sketch of Europe in the earliest Rupelian adopted from Popov et al. (2004)

Carpathian fauna sites shown by asterisks

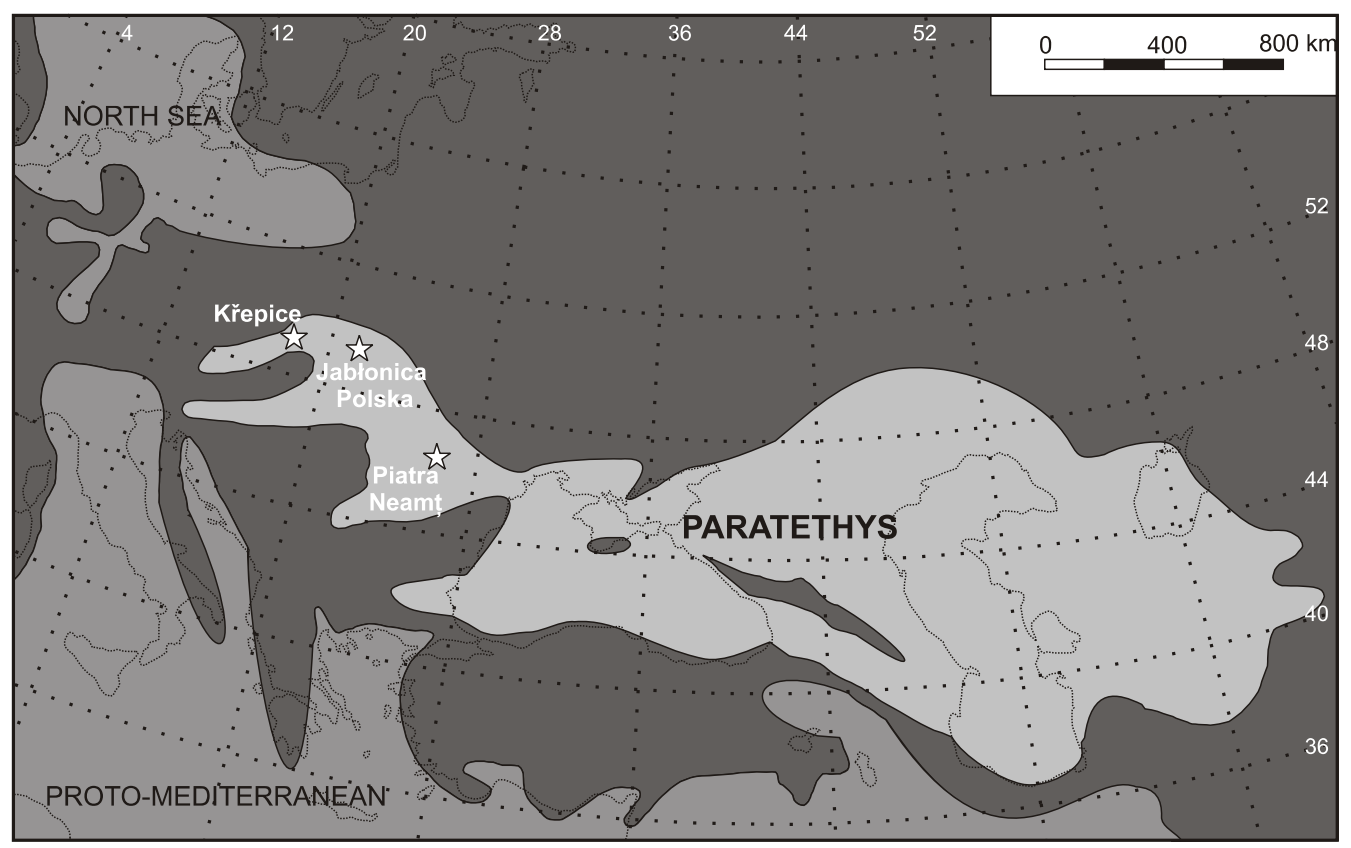

Fig. 14. Palaeogeographical sketch of Europe in the Middle Rupelian adopted from Popov et al. (1993a) and Rusu (1999)

Carpathian fauna sites shown by asterisks

entity as far as shallow-water bivalves are concerned, subsequently distinguished as the Transeuropean Province (Rusu, 1977), the Solenovian Province (Popov et al., 2002) and the Danubian Province (Harzhauser et al., 2002).

After a short time (ca. 2.4 Myr: the time span of NP23 Zone) the Paratethys was differentiated into two large geotectonic units which showed dissimilar environmental histories due to non-synchronous regional tectonic movements controlling marine and non-marine phases (Nevesskaja et al., 1987; Jones and Simmons, 1996; Rögl, 1999; Meulenkamp et al., 2000; Popov et al., 2004). In the case of the Central Paratethys four evolutionary stages have been recognized: to three erected by Seneš (1960), Rusu (1988) added the new term Protoparatethys (Middle Early Oligocene to middle Late Oligocene, Kiscellian) to specify its oldest evolutionary phase. On the other hand, as pointed out by Nevesskaja et al. (1987) the geodynamic history of the Eastern Paratethys may be divided into seven stages. 


\section{FINAL CONCLUSIONS}

The newly collected material, one of three recognized in the Outer Carpathians, is of great importance both in terms of taxonomic diversity and the depositional environments it indicates. The bivalve fauna populating the Carpathian Paleogene Flysch basins during the Early Oligocene (NP23 Zone) (Čtyroký, 1991; Rusu, 1999; and this study) is also of great importance for correlation of the Carpathian Flysch not only with the Kiscellian deposits of both the Hungarian Paleogene Basin (Báldi, 1986; Rusu, 1988) and the Transylvanian Basin (Moisescu, 1964, 1968; Rusu, 1977, 1988), but also with the Solenovian strata of Ukraine, Russia, Georgia and Kazakhstan. Findings of this peculiar bivalve assemblage, typical of the Solenovian of the Paratethyan Euxine-Caspian Basin System, in the Carpathian Paleogene Flysch basins show how the closure of wide connections with the World Ocean (approximately at the boundary between the NP22and NP23 zones) considerably changed environmental features such as salinity, stratification of water column and conditions at the basin bottom. This also shows that the newly formed semiclosed Paratethys was characterized by strong endemism expressed by the presence of uniform shallow-water fauna of small bivalves characterized by the occurrence of endemic genera such as Korobkoviella Merklin, Merklinicardium Popov, Urbnisia Goncharova, Ergenica G. Popov, Janschinella Merklin and Lenticorbula Merklin, and endemic species of the genera Cerastoderma Poli, Parvicardium
Monterosato, Lentidium Cristofori et Jan and Mytilopsis Conrad. This is also the best indicator for conditions of the Solenovian-Early Kiscellian Paratethys with sedimentary characteristics similar to that of the Holocene Black Sea (Rusu, 1977, 1988; Schulz at al., 2005) with pliohaline (estimated salinity between 12 and $15 \%$ ) water oxygenated at the surface and euxinic environmental conditions at the bottom.

Acknowledgements. This paper is a contribution to the joint Polish-Russian Project Cenozoic invertebrate faunas realized within the framework of bilateral cooperation between the Polish Academy of Sciences and the Russian Academy of Sciences. It comprises results of the long-term programme of joint research at the Museum of the Earth in Warsaw and the Borissiak Paleontological Institute in Moscow, directed towards the illustration of various palaeontological and stratigraphic aspects of the Paratethys. The authors express warm and sincere thanks to Dr. A. V. Guzhov (Borissiak Paleontological Institute RAS in Moscow) who has taken the photographs. Dr. A. Dulai (Hungarian Natural History Museum in Budapest), Dr. B. Marinescu (Grigore Antipa National Museum of Natural History in Bucharest) and Dr. A. Rusu (Geological Institute in Bucharest) are thanked for facilitating access to the malacological collections. Prof. N Oszczypko (Jagiellonian Univeristy, Cracow) and Dr. M. Harzhauser (Natural History Museum in Vienna) have kindly offered some suggestions to clarify the content of this paper.

\section{REFERENCES}

Amitrov, O.V., 1996. Paleogeography and climatic zonation of Early Oligocene seas West of Eurasia based on gastropods (in Russian with English summary). Paleontologicheskiy Zhurnal, 1: 3-12.

Amitrov, O.V., 1998. Marine gastropods in the Upper Eocene-Lower Oligocene deposits of the European part of the former Soviet Union, Transcaspian region, Western Siberia and Middle Asia (in Russian). In: Late Eocene-Early Oligocene Geological and Biotic Events on the Territory of the Former Soviet Union. Part II. The geological and biotical events (eds. V.A. Krasheninnikov and M.A. Akhmetiev): 46-49. Publishing office GEOS, Moscow.

Andreyeva-Grigorovich, A.S., 1981. The nannoplankton from Eocene-Oligocene boundary and Oligocene deposits of Armenia and North Caucasus (in Russian). Paleontologicheskiy Sbornik (L'vov), 18: 57-61.

Andreyeva-Grigorovich, A.S., 1987. The nannoplankton and dinocyst from Eocene-Oligocene boundary deposits of the Carpathians (in Russian with English summary). Paleontologicheskiy Sbornik (L'vov), 24: 76-84.

Andreyeva-Grigorovich, A.S., Gruzman, A.D., 1994. The biostratigraphic basis of the Paleogene-Neogene boundary in the Central and Eastern Paratethys. Geologica Carpathica, 45: 333-342.

Andrussow, N.I., 1900. Fossils and recent Dreissenidae of Eurasia: first supplement (in Russian). Travaux de la Société des Naturalistes de St.-Pétersbourg, section de Géologie et de Minéralogie, 29: 59-132.

Báldi, T., 1979. Changes of Mediterranean (?Indopacific) and boreal influence on Hungarian marine molluscan fauna since Kiscellian until Eggenburgian times; the stage Kiscellian. Annales Géologique de Pays Helléniques, Hors série, 1: 39-49.

Báldi, T., 1980. The history of the Early Paratethys (in Hungarian with English summary). Földtani Kozlony, 110: 456-472.

Báldi, T., 1984. The terminal Eocene and Early Oligocene events in Hungary and separation of an anoxic, cold Paratethys. Eclogae Geologicae Helvetiae, 77 : 1-27.
Báldi, T., 1986. Mid-Tertiary stratigraphy and paleogeographic evolution of Hungary. Akadémiai Kiadó, Budapest.

Báldi, T., 1989. Tethys and Paratethys through Oligocene times. Remarks and comment. Geologica Carpathica, 40: 85-99.

Bieńkowska-Wasiluk, M., 2010. Taphonomy of Oligocene teleost fishes from the Outer Carpathians of Poland. Acta Geologica Polonica, 60: 479-533.

Bohn-Havas, M., Lantos, M., Selmeczi, I., 2004. Biostratigraphic studies and correlation of Tertiary planktonic gastropods (pteropods) from Hungary. Acta Palaeontologica Romaniae, 4: 37-43.

Brzobohatý, R., 1981. Izolovane rybi zbytky z menilitovych vrstev Ždanicke jednotky na Moravě. Zemni Plyn a Nafta, 26: 79-87.

Bubik, M., Gregorová, R., Švabenicka, L., 2006. Micropaleontology and fish fauna of the Subchert-Member at Litenčice (in Czech with English summary). Geologicke Vyzkumy na Moravě a ve Slezsku (v roce 2005), 13: 30-31.

Cimerman, F., Jelen, B., Skaberne, D., 2006. Late Eocene benthic foraminiferal fauna from clastic sequence of the Socka-Dobrna area and its chronostratigraphic importance (Slovenia). Geologija, 49: 7-44.

Ciobanu, M., 1977. Fauna fossilă din Oligocenul de la Piatra Neam . Editura Academiei Republici Socialiste Romănia; Bucureşti.

Ciurej, A., Haczewski, G., 2012. The Tylawa Limestones - a regional marker horizon in the Lower Oligocene of the Paratethys: diagnostic characteristics from the type area. Geological Quarterly, 56 (4): 833-844.

Čtyroký, P., 1991. Nalez mekkysu $v$ dynowskych slinovcich (menilitovem souvrstvi) zdanicke jednotky (in Czech). Zprávy o geologických výzkumech $\vee$ roce 1991: 33-34. Vydavatelstvi Ceského geologického ústavu, Praha.

Dreger, J., 1904. Die Lamellibranchiata von Häring bei Kirchbichl in Tirol. Jahrbuch der Kaiserlich-Königlichen Geologischen Reichstanstalt, 53: 253-351. 
Fleszar, A., 1912. Sur quelques fossiles des Carpates. Note préliminaire (in Polish with French summary). Kosmos, 37: 90-95.

Friedberg, W., 1903. Das miozäne Becken von Rzeszów (in polish with Germany summary). Rozprawy Wydziału matematyczno-przyrodniczego Akademii Umiejętności w Krakowie, 43, Serya B: $219-272$.

Garecka, M., 2012. Record of the changes in the Oligocene-Miocene sediments of the Menilite-Krosno series of the Skole Unit based on calcareous nannoplankton studies - biostratigraphy and palaeogeographical implications (Polish Outer Carpathians). Biuletyn Państwowego Instytutu Geologicznego, 453: 1-22.

Gitton, J.L., Lozouet, P., Maestrati, Ph., 1986. Biostratigraphie et paleoecologie des gisements types du Stampian de la region d'Etampes (Essonne). Geologie de la France, 1: 3-101.

Giunta, S., Morigi, C., Negri, A., Guichard, F., Lericolais, G., 2007. Holocene biostratigraphy and paleoenvironmental changes in the Black Sea based on calcareous nannoplankton. Marine Micropaleontology, 63: 91-110.

Gozhyk, P., Semenenko, V., Andreeva-Grigorovich, A., Maslun, N., 2015. The correlation of the Neogene of Central and Eastern Paratethys segments of Ukraine with the International Stratigraphic Chart based on planktonic microfossils. Geologica Carpathica, 66: 235-244.

Gregorová, R., 1997. Evolution of fish and shark faunistic assemblages in Oligocene of the Carpathian Flysch Zone in Moravia and their significance for paleoecology, paleobathymetry and stratigraphy (in Czech with English summary). In: Dynamika vztahů marinniho a kontinentalniho prostředi (ed. Š. Hladilova): 29-35. Sbornik přispevků. Grantovy projekt GAČR 205/95/1211. Masarykova Univerzita v Brně. Brno.

Gregorová, R., 2011. Fossil fish fauna (Teleostei, Selachii) from the Dynow marlstone (Rupelian, NP 23) of the Menilitic Formation at the locality of Litenčice (Czech Republic). Acta Musei Moraviae, Scientiae Geologicae, 96: 3-33.

Gruzman, A.D., 1990. Foraminifers and stratigraphy of the Oligocene and Lower Miocene of the Ukrainian Carpathians (in Russian). Unpublished Ph.D thesis, Ukrainskiy Nauchno-Issledovatelskiy Geologorazviedochnyi Instytut, Lviv.

Gruzman, A.D., Maximov, B.V., Reyfman, L.M., 1962. On the lower Oligocene boundary in the Eastern Carpathians (in Russian). Dokłady AN SSSR, 45: 1110-1112.

Haczewski, G., 1989. Coccolith limestone horizons in the Menilite-Krosno series (Oligocene, Carpathians) - identification, correlation and origin (in Polish with English abstract). Annales Societatis Geologorum Poloniae, 59: 435-523.

Hardenbol, J., Thierry, J., Farley, M.B., Jaquin, T., Graciansky, P.-C., Vail, P.R., 1998. Mesozoic and Cenozoic sequence chronostratigraphic framework of European basins. SEPM Special Publication, 60: 3-13.

Harzhauser, M., Piller, W.E., Steininger, F.F., 2002. Circum-Mediterranean Oligo-Miocene biogeographic evolution - the gastropods' point of view. Palaeogeography, Palaeoclimatology, Palaeoecology, 183: 103-133.

Íslamoğlu, Y., Harzhauser, M., Gross, M., Jiménez-Moreno, G., Coric, S., Kroh, A., Rögl, F., van der Made, J., 2010. From Tethys to Eastern Paratethys: Oligocene depositional environments, paleoecology and paleobiogeography of the Thrace Basin (NW Turkey). International Journal of Earth Sciences, 99: 183-200.

Jones, R.W., Simmons, M.D., 1996. A review of the stratigraphy of Eastern Paratethys (Oligocene-Miocene). Bulletin of the Natural History Museum, 52: 25-49.

Jonet, S., 1947. Présence d'un squale du genre Cetorhinus dans l'Oligocene de Roumanie. Bulletin de la Société belge de Géologie, de Paléontologie et d'Hydrologie, 56: 17-19.

Jonet, S., 1958. Contributions à l'étude des schistes disodyliques Oligocènes de Roumanie, La faune ichthyologique de Homoraciú, District de Prahova, Lisbonne.

Jucha, S., Krach, W., 1962. Nouveaux emplacements de la faune dans la série ménilitique (in Polish with French summary). Acta Geologica Polonica, 12: 227-263.
Karlov, N.N., 1962. On the horizon with Lentidium sokolovi Karlov sp. nov. from the Black Sea Region (in Russian). Bulletin MOIP (Moscow Society of Naturalist), Geology, 37: 101-110.

Kazakhashvili, Zh.R., 1984. Paleobiological history of molluscan fauna from the Solenovian horizon of Georgia (in Russian). Metzniereba, Tbilisi.

Kojumdgieva, E., Sapundgieva, V., 1981. Biostratigraphie de l'Oligocene du bassin de la Haute Thrace d'apres les Molluscques. Geologica Balcanica, 11: 93-114.

Kotlarczyk, J., 1979. Wprowadzenie do stratygrafii jednostki skolskiej Karpat fliszowych (in Polish). In: Badania Paleontologiczne Karpat Przemyskich: Materiały IV Krajowej Konferencji Paleontologicznej, Przemyśl, 25-27 czerwca 1979 r. (ed. J. Kotlarczyk): 14-26. Wydawnictwo AGH, Kraków.

Kotlarczyk, J., Leśniak, T., 1990. Lower part of the Menilite Formation and related Futoma diatomite member in the Skole unit of the Polish Carpathians (in Polish with English summary). AGH, Instytut Geologii i Surowców Mineralnych. Wydawnictwa własne, 23: 1-74.

Kotlarczyk, J., Uchman, A., 2012. Integrated ichnology and ichthyology of the Oligocene Menilite Formation, Skole and Subsilesian nappes, Polish Carpathians: A proxy to oxygenation history. Palaeogeography, Palaeoclimatology, Palaeoecology, 331-332: 104-118.

Kotlarczyk, J., Jerzmańska, A., Świdnicka, E., Wiszniowska, T., 2006. A framework of ichthyofaunal ecostratigraphy of the Oligocene-Early Miocene strata of the Polish Outer Carpathian basin. Annales Societatis Geologorum Poloniae, 76: 1-111.

Krach, W., 1963. Mollusca of the Babica Clays (Paleocene) of the Middle Carpathians. Part I: Gastropoda. Studia Geologica Polonica, 14: 9-152.

Krach, W., 1969. Mollusca of the Babica Clays (Paleocene) of the Middle Carpathians. Part II: Pelecypoda. Studia Geologica Polonica, 29: 5-80.

Krach, W., 1985. The Eocene mollusc fauna from Koniusza near Przemyśl (Polish Eastern Carpathians) (in Polish with English summary). Annales Societatis Geologorum Poloniae, 55: 139-190.

Krajewski, S., Urbaniak, J., 1964. The localities with fauna in the northern Flysch Carpathians. Part I, Metazoans (in Polish with English summary). Biuletyn Instytutu Geologicznego, 179: 1-236.

Krhovský, J., 1981. Microbiostratigraphic correlation in the Outer Flysch Units of the Southern Moravia and influence of the eustasy on their paleogeographic development (in Czech with English summary). Zemni Plyn a Nafta, 26: 665-688.

Krhovský, J., Adamová, J., Hladiková, J., Maslowská, H., 1992. Paleoenvironmental changes across the Eocene/Oligocene boundary in the Ždánice and Pouzdřany units (western Carpathians, Czechoslovakia): the long-term trend and orbitality forced changes in nannofossils assemblages. Knihovnička ZPN (Zemni Plyn a Nafta), 14b, 2: 105-187.

Krhovský, J., Rögl, F., Hamršmid, B., 2001. Stratigraphic correlation of the Late Eocene to Early Miocene of the Waschberg Unit (Lower Austria) with Ždanice and Pouzdřany Units (South Moravia). Schriftenreihe der Erdwissenschaftlichten Kommissionen, 14: 225-254.

Kropaczek, B., 1910. Montienfauna aus dem Flysch der Nord Karpaten von Babica bei Rzeszów. I Teil Gastropoda. Unpublished Ph.D thesis, University of Vienna.

Kropaczek, B., 1917. Kleine Baiträge zur Geologie der nördlichen Karpaten Mittelgaliziens (in Polish with German summary). Sprawozdania Komisji Fizyograficznej Akademii Umiejętności, 51: 106-146.

Kropaczek, B., 1919. Structure géologique des gisements pétrolifères de Borysław-Tustanowice (in Polish with French summary). Stacya Geologiczna w Borysławiu, Drukarnia Uniwersytetu Jagiellońskiego, Kraków.

Laskarew, W.N., 1924. Sur les equivalentes du Sarmatien supérieur en Serbie. In: Recueil de traveaux ofert a M. Jovan Cvijic par ses amis et collaborateurs (ed. P. Vujević): 73-85. Drzhavna Shtamparija, Belgrade. 
Löffler, S.-B., 1999. Systematische Neubearbeitung und Paläoökologische Aspekte der Unter-Oligozänen Molluskenfauna aus den Zementmergeln von Bad Häring (Unterinntal, Tirol). Tübinger Geowissenschaftliche Arbeiten, A54: 1-207.

Marquet, R., Lenaerts, J., Karnekamp, C., Smith, R., 2008. The molluscan fauna of the Borgloon Formation in Belgium (Rupelian, Early Oligocene). Palaeontos, 12: 1-99.

Martini, E., 1971. Standard Tertiary and Quaternary calcareous nannoplankton zonation. In: Proceedings 2nd Planktonic Conference, 2 (ed. A. Farinacci): 739-785. Tecnosciencia, Rome.

Maximov, A.V., 1959. Stratigraphy and molluscan fauna from the Paleogene of the Eastern Carpathians (in Russian). Unpublished Ph.D thesis, University of Lviv.

Maximov, A.V., 1961. Some new species of molluscs from Paleogene deposits of the Eastern Carpathians (in Russian with English summary). Paleontologicheskiy Sbornik (L'vov), 1: 41-50.

Maximov, A.V., 1963. Analyse of the molluscan fauna from the Oligocene deposits of the Ukrainian Carpathians (in Russian). Trudy UkrNIGRI, 3: 212-222.

Maximov, A.V., 1987. Mollusca of the boundary Eocene and Oligocene layers of the Eastern Carpathians (in Russian with English summary). Paleontologicheskiy Sbornik (L'vov), 24: 70-75

Melinte, M.C., 2005. Oligocene palaeoenvironmental changes in the Romanian Carpathians, revealed by calcareous nannofossils. Studia Geologica Polonica, 124: 341-352.

Melinte-Dobrinescu, M., Brustur, T., 2008. Oligocene-Lower Miocene events in Romania. Acta Palaeontologica Romanie, 6 : 203-215.

Merklin, R.L., 1961. On a new Tertiary subgenus of Corbulidae (in Russian). Paleontologicheskiy Zhurnal, 1: 82-88.

Merklin, R.L., 1974. Handbook of bivalves from the Oligocene of the south regions of the USSR (in Russian). Transactions of the Paleontological Institute, Academy of Sciences of the USSR, 145: $1-172$

Meulenkamp, J.E., Sissingh, W., 2003. Tertiary palaeogeography and tectonostratigraphic evolution of the Northern and Southern Peri-Tethys platforms and the intermediate domains of the African-Eurasian convergent plate boundary zones. Palaegeography, Palaeoclimatology, Palaeoecology, 196: 209-228.

Meulenkamp, J.E., Sissingh, W., Londeix, L., Chahuzac, B. Calvo, JP., Daams, R., Studencka, B., Kováč, M., Nagymarosy, A., Rusu, A., Badescu, D., Popov, S.V., Scherba, I.G., Roger, J., Platel, J.P., Hirsch, F., Sadek, A., Abdel-Gawad, G.I., Yaich, C., Ben Ýsmail-Lattrache, K., Bouaziz, S., 2000. Late Rupelian (32-29 Ma). In: Peri-Tethys Atlas, Paleogeographic Maps with Explanatory Notes (eds. J. Dercourt, M. Gaetani, B. Vrielynck, E. Barrier, B. Biju-Duval, M.F. Brunet, J.P. Cadet, S. Crasquin and M. Sandulescu): 171-178, Paris.

Moisescu, V., 1964. O specie noua de Congeria în depozitele Oligocenului superior din nord-vestul Transilvaniei. Studii şi Cercetari de Géologie, Géofizica, Géografie, Sectia Géologie, 9: 251-254

Moisescu, V., 1968. Sur une forme de Janschinella des Couches de Cetate du bassin de Transylvanie. Revue Roumaine de Géologie Géophysique et Géographie. Série de Géologie, 12: 233-236.

Moisescu, V., 1972. Mollusques et échinides stampiens et égériens de la région de Cluj-Huedin-Românaşi (Nord-Ouest de la Transylvanie). Mémoires du Institut Geologique, 16: 5-152.

Monostori, M., 2008. Oligocene environments and their ostracod fauna in Hungary. Hantkeniana, 6: 173-176.

Müller, C., 1970. Nannoplankton Zonen der Unteren Meeresmolasse Bayerns. Geologica Bavarica, 63: 107-118.

Nagymarosy, A., Báldi-Beke, M., 1988. The position of the Paleogene formations of Hungary in the standard nannoplankton zonation. Annales Universitatis Scientiarum Budapestinensis, Sectio Geologica, 28, 3-25.

Nagymarosy, A., Voronina, A.A., 1992. Calcareous nannoplankton from the lower Maykopian Beds (Early Oligocene, Union of Independent States). Knihovnička ZPN (Zemni Plyn a Nafta), 14b, 2: 189-223.

Nevesskaja, L.A., 1961. Changes of molluscan assemblages in shallow marine setting of the Black Sea (in Russian). Proceed- ings Conference on knowledge of the Quaternary Period, 1: 347-354.

Nevesskaja, L.A., 1965. Late Quaternary bivalves of the Black Sea; their systematics and ecology (in Russian). Transactions of the Paleontological Institute, Academy of Sciences of the USSR, 105: 3-391.

Nevesskaja, L.A., Goncharova, I.A., Iljina, L.B., Paramonova N.P., Popov, S.V., Voronina, A.A., Chepalyga, A.L., Babak, E.V., 1987. History of Paratethys. Proceedings of VIIIth Congress of the Regional Committee on Mediterranean Neogene Stratigraphy, Budapest, 15-22 September 1985. Annales Instituti Geologici Publici Hungarici, 70: 337-342.

Nikolaeva, I.A., 1998. Upper Eocene and Lower Oligocene ostracods of Ukraine, the Crimea-Caucasus and Aral-Turgay regions, and Middle Asia (in Russian). In: Late Eocene-Early Oligocene Geological and Biotic Events on the Territory of the Former Soviet Union. Part II. The geological and biotical events (eds. V.A. Krasheninnikov and M.A. Akhmetiev): 39-46. Publishing office GEOS. Moscow.

Nossovsky, M.F., 1962. The bivalves from the Corbula Beds of the Depression at Black Sea (in Russian). Paleontologicheskiy Zhurnal, 3: 29-39.

Oaie, G., Melinte-Dobrinescu, M.C., 2012. Holocene litho- and biostratigraphy of the NW Black Sea (Romanian shelf). Quaternary International, 261: 146-155.

Olszewska, B., 1985. Foraminifera of the Menilite Beds (Polish External Carpathians) (in Polish with English summary). Annales Societatis Geologorum Poloniae, 55: 201-250.

Piller, W.E., Harzhauser, M., Mandic, O., 2007. Miocene Central Paratethys stratigraphy - current status and future directions. Stratigraphy, 4: 151-168.

Popov, S.V., 1994. Zoogeography of the Early Oligocene European basins based on bivalve fauna. Stratigraphy and Geological Correlation, 3: 585-595.

Popov, S.V., Stolyarov, A.S., 1996. Paleogeography and anoxic environments of the Oligocene-Early Miocene Eastern Paratethys. Israel Journal of Earth Sciences, 45: 161-168.

Popov, S.V., Studencka, B., 2015. Brackish-water Solenovian mollusks from the Lower Oligocene of the Polish Carpathians. Paleontological Journal, 49: 342-355.

Popov, S.V., Titova, L.V., 1982. Bivalve molluscs from the analogs of the Solenovian Horizon in Georgia (in Russian). Paleontologicheskiy Zhurnal, 4: 36-48.

Popov, S.V., Ilijna, L.B., Nikolayeva, I.A., 1985. Mollusks and ostracods from the Solenovian horizon of the Eastern Paratethys (in Russian). Paleontologicheskiy Zhurnal, 1: 28-41.

Popov, S.V., Akhmet'ev, M.A., Zaporozhets, N.I., Voronina, A.A., Stolayarov, A.S., 1993a. Evolution of Eastern Paratehys in the Late Eocene-Early Miocene. Stratigraphy and Geological Correlation, 1: 572-599.

Popov, S.V., Voronina, A.A., Goncharova, I.A., 1993b. Stratigraphy and bivalve fauna from the Oligocene and Lower Miocene of the Eastern Paratethys (in Russian). Transactions of the Paleontological Institute, Academy of Sciences of the USSR, 256: 3-257.

Popov, S.V., Akhmetiev, M.A., Burgova, E.M., Lopatin, A.V., Amitrov, O.V., Andreyeva-Grigorovich, A.S., Zaporozhec, N.I., Zherikhin, V.V., Krasheninnikov, V.A., Nikolaeva, I.A., Sytchevskaya, E.K., Scherba, I.B., 2002. Biogeography of the Northern Peri-Tethys from the Late Eocene to the Early Miocene, Part 2: Early Oligocene. Paleontological Journal, 36, Suppl., 3: S185-S259.

Popov, S.V., Rögl, F., Rozanov, A.Y., Steininger, F.F., Scherba, I.G., Kováč, M., 2004. Lithological-paleontological maps of Paratethys. 10 maps Late Eocene to Pliocene. Courier Forschungsinstitut Senckenberg, 250: 1-46.

Popov, S.V., Studencka, B., Amitrov, O.V., 2009a. Oligocene molluscan fauna of the Ukrainian Carpathians (in Russian with English summary). Proceedings of the Institute of Geological Sciences of the NAS of Ukraine (Fossil flora and fauna of Ukraine: palaeoecological and stratigraphic aspects): 282-286.

Popov, S.V., Akhmetiev, M.A., Lopatin, A.V., Burgova, E.M., Sytchevskaya, E.K., Scherba, I.B., Andreyeva-Grigorovich, A.S., Zaporozhec, N.I., Nikolaeva, I.A., Kopp, M.L., 2009 b. 
Paleogeography and biogeography of Paratethys basins (in Russian). Transactions of the Paleontological Institute, Academy of Sciences of the USSR, 292: 7-200.

Prikryl, T., 2013. An annotated list of the Oligocene fish fauna from the Osičko locality (Menilitic Fm.; Moravia, the Czech Republic). Acta Musei Nationalis Prague. Series B, Historia Naturalis, 69 : 195-203.

Rogala, W., 1919. Note préliminaire sur la découverte d'une nouvelle faune paleogéne dans les Karpates Occidentales (in Polish with French summary). Kosmos, 42: 191-192.

Rogala, W., 1925. Matériaux pour la géologie de Karpates. III. Sur la faune et l'âge des "Couches de Popiele" (in Polish with French summary). Kosmos, 50: 932-939.

Rogala, W., 1926. Nouvelles données pour la stratigraphie du flysch karpatique. Mémoire de la 1-ère Réunion de l'Association Karpatique en Pologne, 1-7 septembre 1925/Service Géologique de Pologne, Station Géologique, Borysław.

Rolle, F., 1858. Über die geologische Stellung der Sotzka-Schichten in Steiermark. Sitzungsberichte der Mathematisch-Naturwissenschaftlichen Classe der Kaiserlichen Akademie der Wissenschaften, 13-17: 3-33.

Rögl, F., 1998. Palaeogeographic considerations for Mediterranean and Paratethys seaways (Oligocene to Miocene). Annalen des Naturhistorischen Museums in Wien, 99A: 279-310.

Rögl, F., 1999. Mediterranean and Paratethys palaeogeography during the Oligocene and Miocene. In: Hominoid Evolution and Climatic Change in Europe, I. The Evolution of Neogene Terrestrial Ecosystems in Europe, (eds. J. Agusti, L. Rook and P. Andrews): 8-22. Cambridge University Press.

Rögl, F., Krhovský, J., Braunstein, R., Hamršmid, B., Sauer, R., Seifert, P., 2001. The Ottenthal Formation revised - sedimentology, micropaleontology and stratigraphic correlation of the Oligocene Ottenthal sections (Waschberg Unit, Lower Austria). Schriftenreihe der Erdwissenschaftlichen Kommissionen, 14: 291-346.

Ruchin, L.B., 1935. Descriptions of some rare and new molluscan species from the Paleogene of the Prearalian region (in Russian). Uchenyie Zapiski LGU, 1: 37-52.

Rusu, A., 1977. La stratigraphie des dépots oligocènes du norg-ouest de la Transylvanie (la région de Treznea Hida-Poiana Blenchii (in Romanian with French summary). Anuarul Institutului de Geologie şi Geofizică, 51: 69-224.

Rusu, A., 1988. Oligocene events in Transilvania (Romania) and the first separation of Paratethys. Dâri de Seamâ ale Şedin elor. 5 Tectonica şi Geologie regionala, 72-73: 207-223.

Rusu, A., 1995. Rupelian mollusk fauna of Solenovian type in Transylvania (Romania). Romanian Journal of Stratigraphy, $\mathbf{7 6}$, Supplement 7/1: 101-103.

Rusu, A., 1999. Rupelian mollusk fauna of Solenovian type found in Eastern Carpathians (Romania). Acta Palaeontologica Romaniae, 2: 449-452.

Rusu, A., Popescu, G., Melinte, M., 1996. Excursion Guide of the Field Symposium "Oligocene-Miocene transition and main geological events in Romania" 28 August-2 September 1996. Romanian Journal of Stratigraphy, 76, Supplement, 1: 3-47.

Schultz, O., 2003. Bivalvia neogenica (Lucinoidea-Mactroidea). In: Catalogus Fossilium Austriae (ed. W.E. Piller), 1 (2). Verlag der Österreichischen Akademie der Wissenschaften, Wien.

Schultz, O., 2005. Bivalvia neogenica (Solenoidea-Clavagelloidea). In: Catalogus Fossilium Austriae (ed. W.E. Piller), 1 (3). Verlag der Österreichischen Akademie der Wissenschaften, Wien.

Schulz, H.-M., Bechtel, A., Rainer, T., Sachsenhofer, R.F., Struck, U., 2004. Paleoceanography of the western Central Paratethys during Early Oligocene nannoplankton Zone NP23 in the Austrian Molasse Basin. Geologica Carpathica, 55: 311-323.

Schulz, H.-M., Bechtel, A., Sachsenhofer, R.F., 2005. The birth of the Paratethys during the Early Oligocene: from Tethys to an ancient Black Sea analogue? Global and Planetary Change, 49: 163-176.

Seifert, P., Braunstein, R., Báldi, T., 1991. Korrelation der oligozänen Schichtfolgen von Ottenthal (Waschbergzone, Niederösterreich) mit der Region Kiscell (Budapest, Nordungarn).
Jubiläumsschrift 20 Jahre geologische Zusammenarbeit Österreich-Ungarn. Teil, 1: 109-129.

Seneš, J., 1960. Entwicklungsgeschichte der Paratethys. Mitteilungen der Geologischen Gesellschaft in Wien, 52: 181-187.

Seneš, J., 1966. Bioprovinzielle Zusammensetzung der Paratethyschen Molluskenfaunen und ihre paläogeographische Bedeutung. In: Proceedings of the Third Session in Berne, 8-13 June 1964, (eds. C.W. Drogger, Z. Reiss, R.F. Rutsch and P. Marks): 197-200. E.J. Brill, Leiden.

Seneš, J., 1971. Korrelation des Miozäns der Zentralen Paratethys (Stand 1970). Geologica Carpathica, 22: 3-9.

Steininger, F.F., Wessely, G., 2000. From the Tethyan Ocean to the Paratethys Sea: Oligocene to Neogene Stratigraphy, Paleogeography and Paleobiogeography of the circum-Mediterranean region and the Oligocene to Neogene Basin evolution in Austria. Mitteilungen der Österreichischen Geologischen Gesellschaft, 92: 95-116.

Studencka, B., 1986. Bolesław Kropaczek - discoverer of the Babica Clays (in Polish with English summary). Prace Muzeum Ziemi, 38: 93-128.

Studencka, B., Popov, S.V., Amitrov, O.V., 1999. Oligocene molluscan fauna from the Skibas and Boryslav-Pokut units (the Ukrainian Outher Carpathians) - preliminary report. Geologica Carpathica, 50 , special issue: $75-76$.

Švábenická, L., Bubik, M., Stráník, Z., 2007. Biostratigraphy and paleoenvironmental changes on the transition from the Menilite to Krosno lithofacies (Western Carpathians, Czech Republic). Geologica Carpathica, 58: 237-262.

Taylor, J.D., Williams, S.T., Glover, E.A., 2007. Evolutionary relationships of the bivalve family Thyasiridae (Mollusca: Bivalvia), monophyly and superfamily status. Journal of the Marine Biological Association of the United Kingdom, 87: 565-574.

Veselov, A.A., Sheremeta, V.G., 1964. On the faunistic characteristics of the Solenovian horizon North-Eastern Black Sea area (in Russian). In: The Maikopian deposits and their age-equivalents of Ukraine and Central Asia (ed. O.S. Vialov): 101-122. Naukova Dumka, Kiev

Veselov, A.A., Lul'eva, S.A., 1980. An age of the Polbian horizon from the Oligocene of the southern USSR (in Russian). Bulletin of the Academy of Sciences of the USSR, ser. Geology, 11: 67-71.

Voronina, A.A., Popov, S.V., 1984. Solenovian horizon from Eastern Paratethys (in Russian). Bulletin of the Academy of Sciences of the USSR, ser. Geology, 9: 41-53.

Voronina, A.A., Popov, S.V., 1985. Main features of the evolution of the eastern Paratethys in the Oligocene and Lower Miocene. Annales Universitatis Scientiarum Budapestinensis de Rolando Eötvös nominatae. Sectio geologica, 25: 87-95.

Vyalov, O.S., Andreeva-Grigorovich, A.S., Bashkirov, M.P., Danish, V.V., Gavura, S.P., Ivanik, M.M., Kruglov, S.S., Kul'chitskii, Ya.S., Lozynyak, P.Yu., Polivtsev, A.V., Ponomareva, L.D., Reifman, L.M., Smirnov, S.E., Sovchik, Ya.V., 1996. Region I. Ukrainian Carpathians and Fore-Carpathians (in Russian). In: Late Eocene-Early Oligocene Geological and Biotic Events on the Territory of the Former Soviet Union. Part I. The Regional Geology of the Upper Eocene and Lower Oligocene (eds. V.A. Krasheninnikov and M.A. Akhmetiev): 10-21. Publishing office GEOS, Moscow.

Wasiluk, R., 2015a. Szczegółowa Mapa Geologiczna Polski w skali 1:50 000, arkusz Krosno (in Polish). Państwowy Instytut Geologiczny - Państwowy Instytut Badawczy, Warszawa.

Wasiluk, R., 2015b. Objaśnienia do Szczegółowej Mapy Geologicznej Polski w skali 1:50 000, arkusz Krosno (in Polish). Państwowy Instytut Geologiczny - Państwowy Instytut Badawczy, Warszawa.

Wiśniowski, T., 1908. Atlas Geologiczny Galicji, tekst do zeszytu 21: arkusz Dobromil (in Polish). Komisja Fizjograficzna Akademii Umiejętności. Kraków.

Wójcik, K., 1903. Dolno oligoceńska fauna Kruhela małego pod Przemyślem (Warstwy z Clavulina Szabói). Część I. Otwornice i mięczaki. Rozprawy Wydziału Matematyczno-Przyrodniczego Akademii Umiejetności. Serya III, Nauki Biologiczne, 3B: 489-569. 